\title{
Ideational and Interpersonal Metafunctional Profiles of the Chinese Grammar
}

\author{
Elaine Yin Ling Ng \\ The Open University of Hong Kong, Hong Kong, China
}

\begin{abstract}
There has been little research conducted on the applicability of Halliday's (1994) SFG (systemic functional grammar) framework to the analysis of Chinese translated texts and the possible adjustments needed to make the model fit for comparative description dealing with translation from English into Chinese. More has been done to explore the differences in the thematic structure between English and Chinese while relatively little was discussed with regard to the ideational and interpersonal metafunctions of the Chinese language. This paper aims to test the applicability of systemic functional linguistics to the study of Chinese translated texts with regard to the transitivity and modality systems, and suggest aspects of the lexicogrammatical features of the SFG model that need to be adjusted to make it more serviceable for the analysis of Chinese translated texts. The supporting data are drawn from selected examples from two parallel corpora of the three-day battle in Hemingway's The Old Man and the Sea (1952), consisting of 1,388 clause complexes extracted from the English original and its four Chinese translations of the novella compiled manually with reference to Halliday's (1994) transitivity model and Simpson's (1993) model of point of view. The study contributes further samples of text instances to demonstrate the "meaning potentials" of English and Chinese, support the applicability of systemic functional linguistics to the analysis of Chinese translated texts, and proposes to modify aspects of the SFG model according to the unique features of the Chinese grammar and the specific purpose of study for translation description of Chinese texts.

Keywords: ideational and interpersonal metafunctions of the Chinese grammar, applicability of Halliday's systemic functional linguistics to the study of Chinese translated texts, the transitivity system in Chinese, modalization and modulation of the modality system in Chinese
\end{abstract}

\section{Introduction}

\section{Background}

Halliday's (1994) SFG (systemic functional grammar), which relates linguistic choices to their wider sociocultural settings, has been applied to the analysis of Chinese translated texts since the 2000s, as seen in representative works by LI's Yupian Fanyi Yinlun (An Introduction to Discourse and Translation) (2001), XIU's Xin Yixue Lungao (Discussion Into New Translation Studies) (2001), and Li's A Text-Based Study of the Grammar of Chinese From a Systemic Functional Approach (2003). However, research on the application of SFG to the analysis of Chinese translated texts is still preliminary, and there has not yet developed a systematic and comprehensive discourse framework which can be employed for translation research dealing with translation into Chinese (HUANG, 2006, p. 16). In fact, as Matthiessen (2001, pp. 41-42) observed, translated 
texts are not commonly referred to or included as an object of investigation in contrastive linguistics research, and contrastive linguistics and translation studies are still basically two independent disciplines without much overlap in their areas of research. Matthiessen (2001) located the study of translation within functional linguistics and calls attention to treat translation as a phenomenon in its own right. She also demonstrates how linguistics and translation research can inform one another.

Regarding the application of Halliday's SFG model to translation analysis, Munday (2001, p. 101) remarked that the Hallidayan model used as an analytical framework for translation comparison is usually English-language oriented, some aspects of the model, particularly the textual and transitivity structures, should be adapted for the study of non-European languages (Munday, 2002, p. 91). Nevertheless, there has yet little research conducted on the applicability of Halliday's SFG framework to the analysis of Chinese translated texts and the possible adjustments that are needed to make the model fit for comparative description of Chinese target texts. More has been done to explore the differences in the thematic structure between English and Chinese as seen in the studies conducted by PANG (1993) and LI (2002), while relatively little was discussed with regard to the ideational and interpersonal metafunctions of the Chinese language, particularly, their application to the description of Chinese translated texts. Except for LI's (2003) work, who has analyzed Chinese translated texts and contributed comparative descriptions of not only the textual metafunction, but also ideational and interpersonal metafunctions between Chinese and English.

Matthiessen (2001, pp. 73-78) contextualized translation from a "wider environment" to a "narrower environment" according to a hierarchy of stratification, and assesses translation equivalence in a decreasing strata ranging from the widest scope of "context", "semantics", and "lexicogrammar" to the narrowest strata of "phonology". She observes that "translation equivalence" can be attained to a higher degree as translation takes place in a wider environment. Conversely, greater "translation shifts" are uncovered at the lower levels of "lexicogrammar" and "phonology”. Matthiessen (2001, p. 116) remarked further that one of the pressing tasks for the study of translation is to conduct detailed lexicogrammatical analysis of source texts and their corresponding target texts for translation comparison since this type of research has remained sparse. For example, HUANG (2006) studied the English translations of selected Chinese classical poems from the perspectives of the experiential, logical, interpersonal, and textual functions, and attempts to test the applicability of systemic functional linguistics to the study of Chinese translations. However, his analyses focus more on the English translations of the Chinese originals rather than the Chinese translations of the English originals. Although he applies aspects of the model to analyze the Chinese poetry, they are generally not very close comparative descriptions of the lexicogrammatical features between the Chinese originals and their English translations with the aim of identifying microstructural shifts. ZHANG (2005) and SHANG (2003) examined English source texts and their Chinese translations according to the theory of context of situation (field, tenor, and mode) and context of culture. Similarly, they appear to compare the source and the target text(s) more at the level of semantics rather than that of lexicogrammar for the categorization of shifts in the group or word rank although they also scrutinize closely shifts in structure and meaning in a few free-standing sentences.

\section{Aims, Focus, and Methods of the Study}

This paper aims to test the applicability of systemic functional linguistics to the study of Chinese translated texts with regard to aspects of the lexicogrammar of the transitivity and modality systems at the clause, group, and word ranks, and explore the possible modifications to the SFG framework that are needed to 
make it serviceable for the analysis of Chinese translated texts. The study attempts to conduct comparable systemic functional descriptions of Chinese and English against the background of a general systemic functional theory of language. It is based on the assumption that languages are too far complex to be viewed as "unified phenomena" that can be described by a single general theory of language. Each language is a unique system and thus requires particular sets of linguistic descriptions against the background of generalization across a wide range of languages (Caffarel, Martin, \& Matthiessen, 2004, pp. 5-6).

The descriptions conducted in this study are grounded on data collected from four Chinese translations of a narrative of an English literary text. Specifically, the data are drawn from two parallel corpora of the three-day battle in Hemingway's The Old Man and the Sea (1952). The author compiled with reference to Halliday's (1994) transitivity model and Simpson's (1993) model of point of view for her published Ph.D. research (Ng, 2010). The two corpora comprise an English original of a narrative of about 70 pages of the old man's three-day battle with the marlin and its four Chinese translations produced ${ }^{1}$ in modern China. The original text chosen for the compilation of the corpora consists of about two third of the novella totaling 22,024 words, and the four translations total roughly 138,745 words. The two corpora were constructed manually for the investigation of selected features of transitivity and modality. For the transitivity system, there are a total of 1,277 clauses of 52 sub-categories of the material (711 clauses, 15 subcategories), mental (257 clauses, 23 subcategories), behavioral (56 clauses, four subcategories), relational (206 clauses, eight subcategories), and existential processes (47 clauses, two subcategories) compiled. As for the modality system, there are a total of 111 clauses, accounting for about $8 \%$ (out of 1,388) of the total number of clauses of the two corpora investigated. With reference to Simpson's (1993) model of point of view, the mini parallel corpus examines the use of demotic modals "must”, “can”, “could”, “will”, “would”, and "generic statements” epistemic modals such as "may”, "perhaps”, “might have”, "maybe I’ll”, and the boulomaic modal "wish”.

The study aims to provide a sketch of the similarities and differences between English and Chinese in aspects of the ideational and interpersonal metafunctional profiles of the SFG model. The supporting data are drawn from selected examples of text instances from the 1,388 clause complexes extracted from the three-day battle in Hemingway's The Old Man and the Sea. The description of Chinese is modeled on the basis of the lexicogrammatical system of English by reference to evidence of text instances. Attempts are made to find out the resemblances between English and Chinese against the background of a general systemic functional theory of language. The study will conduct grammar-based discourse analysis of selected examples from the two corpora as supporting evidence, which is basically qualitative in nature. Nevertheless, other than qualitative analysis, the study, to a limited extent, also incorporates the quantitative tool as a subsidiary means of investigation. For the transitivity system, under each of the five categories proposed to be adjusted for the Chinese system, a list of 10 more examples selected from the parallel corpus are provided (as listed in the Appendix). They are further textual instances supporting the description of aspects of the transitivity system of the Chinese language. For the modality system, the frequencies of the translations of a range of modal operators are outlined, which provide some light into their representativeness in the Chinese system. The quantitative profiles supplement the qualitative data gathered from the analysis of isolated instances as a combined research tool to generate more valid findings for the empirical study.

1 The four Chinese translations of The Old Man and the Sea investigated are respectively the one produced by HAI Guan (1957), WU Lao (1987), LI Xi-yin (1987), and ZHAO Shao-wei (1987). 
In terms of the hierarchy of stratification as a dimension of linguistic description in systemic functional linguistics, the contrastive linguistic analysis in this study is conducted basically at the level of "lexicogrammar"; in terms of rank, it is realized at the "clause", "group", and "word" ranks. This is a narrower environment where more "translation shifts" are generated because of greater disparity between the two languages in a smaller unit of grammar. In terms of the cline of instantiation of a language system, the study is located more at the instance pole rather than the potential pole since the choices made in the translation process are viewed as actual textual instances of the overall linguistic system. They are particular instances formed as the source text and the target text unfolds in the creation of meaning, and thus the study is grounded firmly in the notion of language in use. It is intended that the examples selected from the two corpora as illustrations in this study will serve to accumulate more textual instances to support the meaning potentials of the language systems of Chinese and English that lie higher up the cline of instantiation.

\section{Outline of the Paper}

The paper falls into four sections: First, this section which is the introduction outlining the aims, focus, and methods of the study. The second section concentrates on the ideational metafunction of the Chinese language. The author will first explore the inherent linguistic differences between English and Chinese in their transitivity structures, then suggest certain aspects of the lexicogrammar of the SFG model that could be adjusted for the study of Chinese translated texts. The third part is devoted to the interpersonal dimension of the Chinese language. The author will compare the systems of modalization and modulation between English and Chinese with examples selected from the parallel corpus compiled in her above-mentioned research as illustrations. The author will also provide a brief review of Simpson's (1993) point of view model based on which the mini modality corpus was compiled. After that the author will propose the sets of Chinese modals that can be included under the categories of Positive Shading Modality and the Negative Shading Modality of Simpson's (1993) model, and explore their applicability for the investigation of narrative point of view in Chinese translated texts. The paper ends with a conclusion restating the major observations from this study and provides some suggestions for future research.

\section{Ideational Metafunction of the Chinese Language}

As introduced above with regard to the transitivity corpus, the author compiled a total of 1,277 clauses of 52 sub-categories of the material (711 clauses, 15 subcategories), mental (257 clauses, 23 subcategories), behavioral (56 clauses, four subcategories), relational (206 clauses, eight subcategories), and existential processes (47 clauses, two subcategories) in the parallel corpus of the three-day battle in the novella. Regarding the translation of the transitivity system, the author found that all the sub-categories of the five process types as identified in English, indeed, have their similar counterparts in Chinese, except that because of the inherent differences between the two languages, particularly, with regard to: (1) the aspect and phase systems; and (2) the configuration of the participants in the process, sometimes some of the clause constituents of a particular process type in English may appear in a different form or expressed in a different process type in Chinese. The following are some examples selected from the transitivity corpus compiled as illustrations:

(1) Differences in the aspect and phase systems, for example, the unmarked perfective phase in English is changed to the unmarked imperfective aspect in Chinese.

The unmarked phase of a verb in English is completive which implies the closure of the process while that 
in Chinese is the inceptive/conative which assumes the unfolding of the process (Halliday \& Matthiessen, 1999, p. 308). Therefore, sometimes the perfective phase in English is shifted to the imperfective verbal aspect in Chinese by the use of the progressive markers “着” zhe and “住” zhu (see Examples 1-3):

Example (1) and he steered with the tiller under his arms (512) ${ }^{2}$

$\begin{array}{lllll}\text { 他把 } & \text { 舵柄 } & \text { 夹在 } & \text { 胳肢 窝里 } & \text { 掌着舵 (HAI, 512) } \\ \text { ta ba } & \text { duobing } & \text { jia zai } & \text { gezhi guoli } & \text { zhangzhe duo } \\ \text { he } & \text { tiller } & \text { put under } & \text { his arms } & \text { steered }\end{array}$

Example (2) and put his foot on the coils (406)

\begin{tabular}{|c|c|c|c|c|}
\hline 一只 & 脚 & 踩住 & 钓丝 & 卷儿 $(\mathrm{HAI}, 406)$ \\
\hline & jiao & $\frac{\text { caizhu }}{\text { stepned }}$ & diaosi & juan er \\
\hline
\end{tabular}

Example (3) and he pushed against the wood to be warm (690)

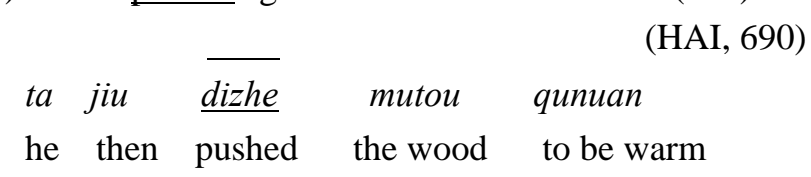

(2) Differences in the configuration of participants in the process of a particular process type, for example, quality attributes construed as "nominals" in intensive attributive clauses in English are changed to "verbals" in Chinese.

In English, while qualities of participants are realized by nominals in the form of adjectives in intensive attributive clauses, they are construed as verbals in the form of adjectival verbal groups in Chinese (Halliday \& McDonald, 2004, p. 358), such as Examples (4)-(6):

Example (4) 1

He was sorry for the birds (1035)

\begin{tabular}{|c|c|c|}
\hline & & 1 \\
\hline 他 替 & 乌雀们 & 伤心 (HAI, 1035) \\
\hline Ta $\underline{t i}$ & niaoquemen & shangxin \\
\hline He for & birds & was sad \\
\hline & & 2 \\
\hline
\end{tabular}

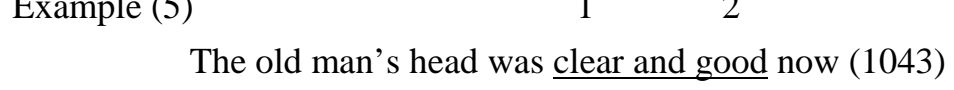

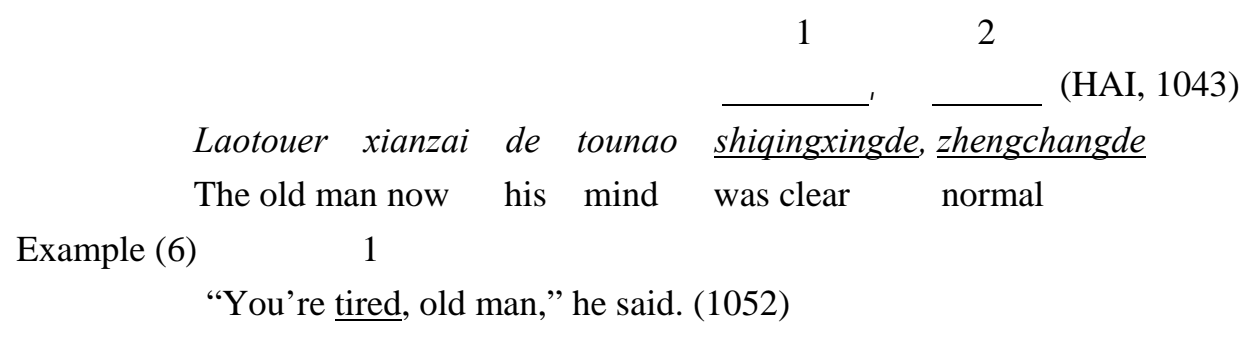

\footnotetext{
${ }^{2}$ Examples are selected from the parallel corpus of The Old Man and the Sea, the author compiled to illustrate the differences between English and Chinese in the transitivity system. The number in parentheses beside each example given refers to the number of the clause labelled originally in the corpus.

${ }^{3}$ There are altogether four Chinese translations in addition to the English original of The Old Man and the Sea included in the parallel corpus compiled. They are respectively the one produced by HAI Guan (1957), WU Lao (1987), LI Xi-yin (1987), and ZHAO Shao-wei (1987). The surname before the number in parentheses in each example quoted refers to the respective version of the four studied in the research.
} 


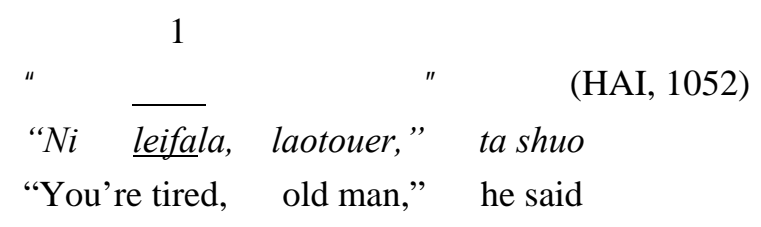

(3) Differences in the construction of elements in the clause, for example, circumstantial elements construed as minor processes in English are changed to full processes in Chinese.

A circumstance, realized by a prepositional phrase, is construed as a minor process in English, whereas in Chinese, it can be constructed as a figure on its own, realized by a coverbal phrase (a coverb is a preverb-prepositive verb—similar to a prepositional phrase in English) plus a post-noun of position or facet or a verbal group as a full process (Halliday \& Matthiessen, 1999, p. 308; Halliday \& McDonald, 2004, p. 317) (see Examples 7-9). The following are some examples:

(a) A prepositional phrase in English is changed to a verbal group in Chinese:

Example (7) 1

and put the skiff on her course (33)

1

$\begin{array}{lllll}\text { 然后 } & \text { 按照 } & \text { 原来的路线 } & \text { 把 } & \text { 船 } \quad \text { 开回去 (HAI, 33) } \\ \text { ranhou } & \begin{array}{l}\text { anzhao } \\ \text { then }\end{array} & \text { following the original route } & \text { ba luxian } & \text { chuan kaihuiqu } \\ \text { the skiff sailed }\end{array}$

Example (8)

12

and allowed himself to be pulled forward against the wood (76)

2

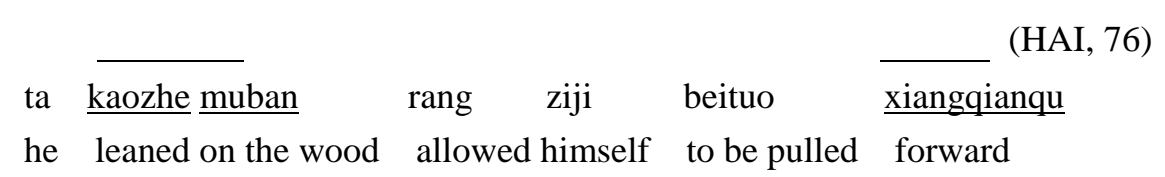

(b) A prepositional phrase in English is changed to a coverbal phrase plus a post-noun of position or facet:

Example (9) 1

2 3

and he loved to walk on them on the beach after a storm (953) $32 \quad 2 \quad 1$

他 喜欢 在一场风暴过后每海滩上 踩在它们身上 (HAI, 953)

ta xihuan zaiyichang fengbao guohou zaihaitanshang caizai tamen shenshang he loved after a storm on the beach walked on them

Despite the differences mentioned above, the author found the overall construction of the five process types and their clause constituents share many similarities between English and Chinese. As Halliday and Matthiessen (1999) remarked:

Chinese and English share many common features in the construction of the ideational base. Thus, if we consider how they construe happenings as "quanta of experience" the two languages are to a large extent congruent: Chinese sequences tend to correspond to English sequences, and Chinese figures to English figures. (p. 314)

Likewise, Halliday and McDonald (2004, pp. 312-313) observed that Chinese and English share a similar metafunction/rank matrix despite the notable differences in that the lowest rank operates in the group rather than the word in a clause, and the functions between certain ranks are sometimes indeterminate. Although there 
are differences in some of the elements of the transitivity system between the two languages, generally the author was still able to apply the model to categorize systematically five types of clauses of the English original, on the basis of which the author managed to compile a corresponding profile of linguistic features for the Chinese target texts for translation comparison. However, difficulties would be encountered if the author applied the model the other way round to first categorize various types of clauses in a Chinese source text, and then sought to identify shifts in an English target text. In such case, some sort of adjustments is needed in order to make the model serviceable for the analysis of Chinese translated texts, particularly for corpus-based studies which investigate patterns of choices instead of isolated instances. However, due to space considerations, in the following, the author will just concentrate on explaining how the transitivity model would have to be adapted in Chinese for the analysis of: (1) aspect and phase; (2) coverbal phrase; (3) the dispositive bă construction; (4) circumstance preceding process; and (5) serial verbal construction, since all these are unique features in Chinese that should be analyzed specially by a SFG model which is specific to the language studied. The suggestions given are by no means exhaustive, but they are prominent features in the Chinese language that appear to be notably different from English in the parallel corpus of The Old Man and the Sea compiled. The author will first introduce under each category the concepts concerned, then provide the breakdowns of the examples selected from the transitivity corpus as support. In addition, a list of 10 more examples from the transitivity corpus for each category is outlined in the appendix as text instances for further reference.

\section{Aspect and Phase}

Chinese is non-inflectional; time is not construed grammatically as tense, but as aspect. A process is not construed as past, present or future relative to the time of speaking, but as imperfective or perfective relative to the context. There are two major temporal systems in Chinese: Aspect and Phase. They are essential for the definition of process types since different types of process have different implications with regard to time. In aspect, a process is construed as "imperfective” (ongoing), "perfective” (culminating indicating closure), or "neutral” (an unmarked option). Perfective aspect includes: (1) perfective proper; and (2) experiential; imperfective aspect includes: (1) durative; and (2) progressive (Halliday \& McDonald, 2004, pp. 353, 380). The system of verbal aspect is illustrated in Table 1.

Table 1

Verbal Aspect in Chinese

\begin{tabular}{|l|l|l|}
\hline \multicolumn{2}{|c|}{ Aspect type } \\
\hline Neutral & \multicolumn{2}{|c|}{ 打 da “hits” } \\
\hline \multirow{2}{*}{ Perfective } & Perfective proper & 打了 da le “has hit” \\
\cline { 2 - 3 } & Experiential & 打过 da guo “has once hit” \\
\hline \multirow{2}{*}{ Imperfective } & Durative & 打着 da zhe “is (in the state of) hitting” \\
\cline { 2 - 3 } & Progressive & 在打 zai da “is (currently) hitting” \\
\hline
\end{tabular}

There are two separate aspect systems in Mandarin. The first is verbal aspect, marked by a particle or a coverb (在 zai) attached to the verbal group in the case of the progressive; the second is clausal aspect, marked by a particle in the final position of a clause. In Chinese, the unmarked process is inceptive/conative (i.e., it implies attempt and marks the phase of success), whereas in English, the unmarked process is completive (i.e., it implies success and marks the process of attempt) (Halliday \& Matthiessen, 1999, p. 308; Halliday \& McDonald, 2004, pp. 9, 381-383). The following are the examples of verbal and clausal aspects (see Tables 2-4): 
Table 2

Verbal (Perfective) Aspect

\begin{tabular}{|c|c|c|c|}
\hline \multicolumn{4}{|l|}{ Example (10) } \\
\hline $\begin{array}{l}\text { 揍 } \\
\text { zou } \\
\text { hit } \\
\end{array}$ & $\frac{了}{\underline{\underline{l e}}}$ & $\begin{array}{l}\text { 它 } \\
\text { ta } \\
\text { it }\end{array}$ & $\begin{array}{l}\text { 一下 (HAI, 208) } \\
\text { yixia } \\
\text { once }\end{array}$ \\
\hline Process (material) & Aspect (verbal: perfective) & Goal & Circumstance (manner) \\
\hline \multicolumn{4}{|l|}{ Example (11) } \\
\hline $\begin{array}{l}\text { 我们 } \\
\text { Women } \\
\text { We } \\
\end{array}$ & $\begin{array}{l}\text { 请求 } \\
\text { qingqiu } \\
\text { begged }\end{array}$ & $\frac{\text { 了 }}{\underline{l e}}$ & $\begin{array}{ll}\text { 她的 } & \text { 宽恕 (HAI, 257) } \\
\text { tade } & \text { kuanshu } \\
\text { her } & \text { forgiveness }\end{array}$ \\
\hline Actor & Process (material) & Aspect (verbal: perfective) & Goal \\
\hline
\end{tabular}

Table 3

Verbal (Imperfective) Aspect

\begin{tabular}{|c|c|c|}
\hline \multicolumn{3}{|l|}{ Example (12) } \\
\hline $\begin{array}{l}\text { 抓 } \\
\text { zhua } \\
\text { held } \\
\end{array}$ & $\begin{array}{l}\text { 住 } \\
z h h u \\
\underline{y}\end{array}$ & $\begin{array}{l}\text { 细钓丝 (WU, 2) } \\
\text { xidiaosi } \\
\text { the small line }\end{array}$ \\
\hline Process (material) & Aspect (verbal: imperfective) & Goal \\
\hline \multicolumn{3}{|l|}{ Example (13) } \\
\hline $\begin{array}{l}\text { 掌 } \\
\text { zhang } \\
\text { held }\end{array}$ & $\begin{array}{l}\text { 着 } \\
\underline{z h e}\end{array}$ & $\begin{array}{l}\text { 舵 (WU, 513) } \\
d u o \\
\text { the tiller }\end{array}$ \\
\hline Process (material) & Aspect (verbal: imperfective) & Goal \\
\hline
\end{tabular}

\section{Table 4}

Clausal (Perfective) Aspect

\begin{tabular}{|l|l|l|l|l|l|}
\hline \multicolumn{2}{|l|}{ Example (14) } \\
\hline $\begin{array}{l}\text { 他 } \\
\text { ha }\end{array}$
\end{tabular}

As for the system of phase, it contains two categories: neutral and completive. Completive phase divides into two subtypes: directional and resultative, both types are realized by the addition of post-verb. The directional subtype of post-verb divides into vectorial (ascend/descend, enter/exit, cross, return, and rise) and orientational (come/go, i.e., towards/away from the speaker). Resultative post-verbs contain six classes: qualitative, mental, change of state, directional, phasal, and exhaustive, as proposed by MacDonald (1994, pp. 337-342, as cited in Halliday \& McDonald, 2004, p. 383). Table 5 lists some examples of the two types of completive phase (see Examples 16-25). 
Table 5

Phase System in Chinese

\begin{tabular}{|c|c|c|c|}
\hline Phase type & \multicolumn{3}{|l|}{ Phase subtypes } \\
\hline Neutral & \multicolumn{3}{|l|}{ 钓 } \\
\hline \multirow{7}{*}{ Completive } & \multirow[t]{2}{*}{$\begin{array}{l}\text { Directional (realized } \\
\text { by a post-verb) }\end{array}$} & $\begin{array}{l}\text { Vectorial } \\
\text { (ascend/descend, } \\
\text { enter/exit, cross, return, } \\
\text { and rise) }\end{array}$ & 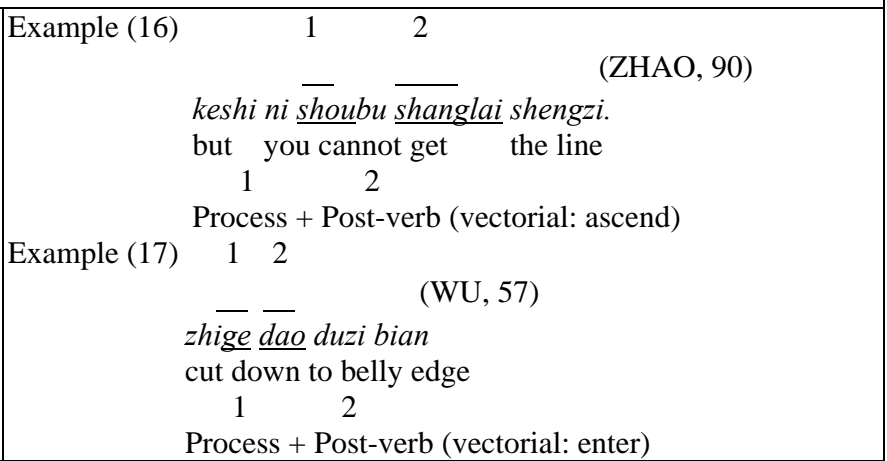 \\
\hline & & Orientational (come/go) & 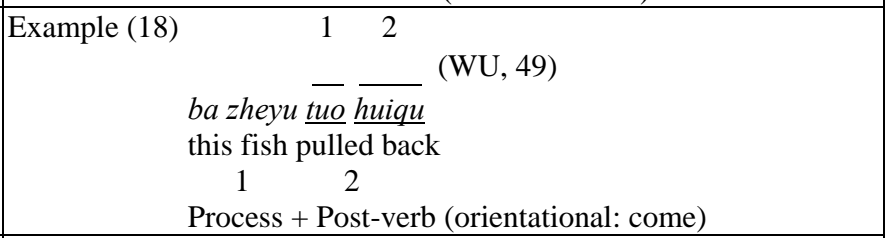 \\
\hline & \multirow{5}{*}{$\begin{array}{l}\text { Resultative (realized } \\
\text { by a post-verb) }\end{array}$} & Qualitative & 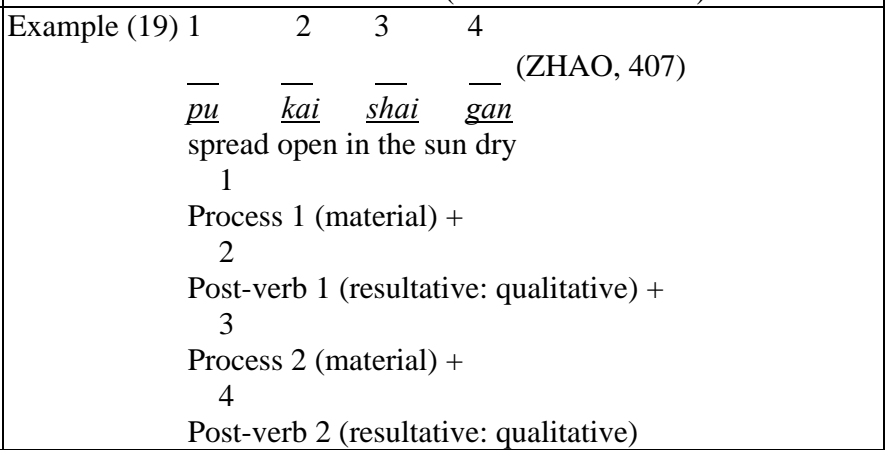 \\
\hline & & Mental & 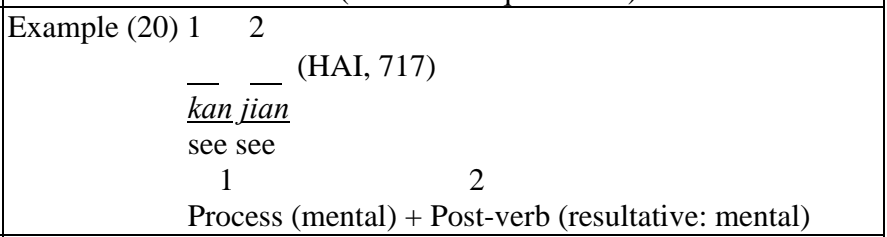 \\
\hline & & Change of state & 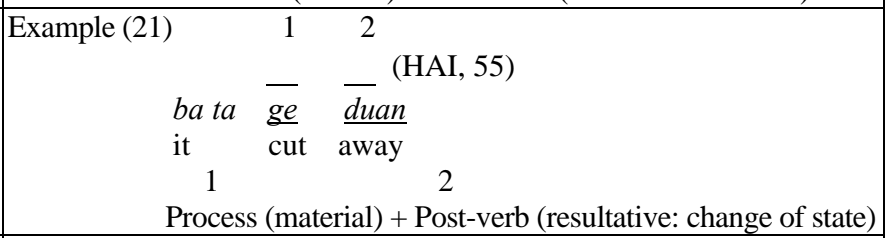 \\
\hline & & Diroctionol/Docition & 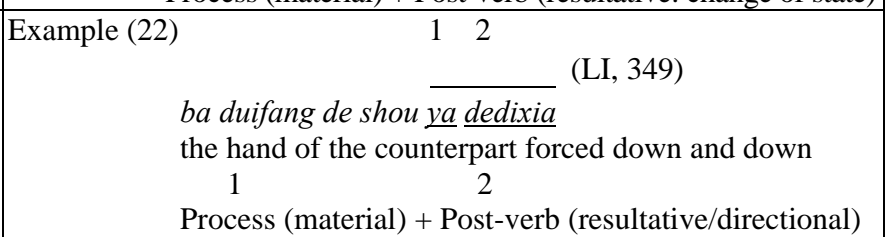 \\
\hline & & Directuonal/rostuonal & 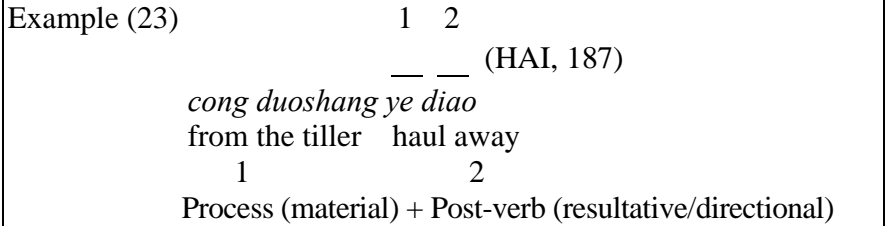 \\
\hline
\end{tabular}


(Table 5 continued)

\begin{tabular}{|c|c|c|c|}
\hline Phase type & \multicolumn{3}{|l|}{ Phase subtypes } \\
\hline Neutral & \multicolumn{3}{|l|}{ 钓 } \\
\hline & \multirow[b]{2}{*}{$\begin{array}{l}\text { Resultative (realized } \\
\text { by a post-verb) }\end{array}$} & Phrasal & \begin{tabular}{|l} 
Example (24) 12 \\
够 着 \\
$\begin{array}{l}\text { gouzhe } \\
\text { pulled }\end{array}$ the liaosi \\
1 \\
Process (material) + Post-verb (resultative: phasal)
\end{tabular} \\
\hline Completive & & Exhaustive & 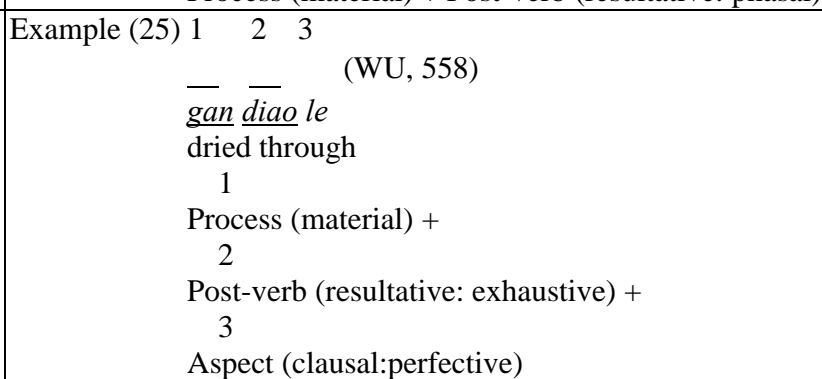 \\
\hline
\end{tabular}

\section{Coverbal Phrase}

Coverbal phrase is a unique class of phrase in Chinese. It is formed by a coverb and a nominal group, which is analogous to a prepositional phrase functioning as a minor process in English. The coverbs commonly used in Chinese are “给” (gei), “跟” (gen), “在” (zai), “到” (diao), and “向” (xiang). They indicate circumstantial meanings related to place, accompaniment, means and so on. A locative phrase preceded by a coverb contains a nominal group modified by a post-noun of position. The coverb indicates the location or direction, and the post-noun the relative position or facet. A coverbal phrase follows a verb. It is circumstance that expresses the outcome of the process (Halliday \& McDonald, 2004, pp. 317, 378). The following are several examples of coverbal phrases (see Examples 26-30 in Table 6).

Table 6

Coverbal Phrases

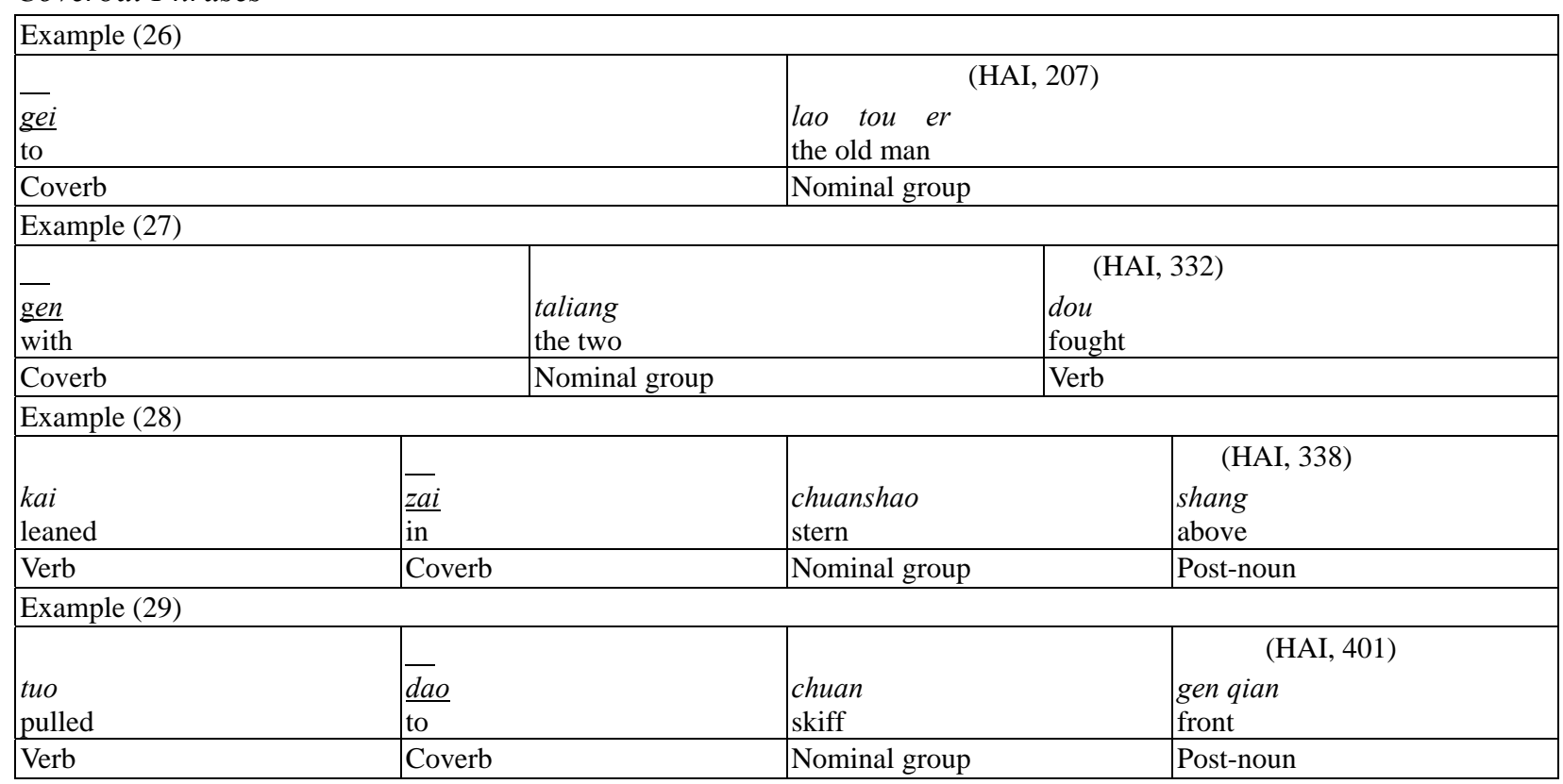


(Table 6 continued)

Example (30)

\begin{tabular}{|l|l|l|l|}
\hline $\begin{array}{l}\text { 倒 } \\
\text { dao } \\
\text { flowed }\end{array}$ & $\begin{array}{l}\text { 向 } \\
\text { xiang } \\
\text { to }\end{array}$ & $\begin{array}{l}\text { 船头 } \\
\text { chuantou } \\
\text { skiff head }\end{array}$ & $\begin{array}{l}\text { libianqu } \\
\text { inside }\end{array}$ \\
\hline Verb & Coverb & Nominal group & Post-noun \\
\hline
\end{tabular}

\section{The Dispositive bă Construction}

The $b \breve{a}$ construction is unique in Chinese, and it has no counterpart in English (Li, 2005, p. 184). The word $b a \breve{~ h a s ~ c h a n g e d ~ f r o m ~ f u n c t i o n i n g ~ a s ~ f u l l-f l e d g e ~ v e r b ~ t o ~ b e c o m e ~ a ~ c o v e r b ~ o f ~ s p e c i f i c ~ v o i c e ~ m a r k i n g ~}$ (Chao, 1968; Li \& Thompson, 1981, as cited in Li, 2005, p. 196). Hopper and Thompson (1980) suggested that the $b \breve{a}$ construction is highly transitive, and that the "subject" has to behave actively (as cited in Li, 2005, p. 192). The coverb bă, meaning, "to grasp", moves the object before the verb in the pattern of "subject $+b \breve{a}+$ object + verb”. The noun phrase or object following $b \breve{a}$ is particularly favored when the goal is clearly indicated and the process is extended by completive or non-completive phase, often completive by perfective aspect. The $b a ̆$ construction is mainly found in material clauses, and a few in verbal and mental clauses marked for completive aspect (Halliday \& McDonald, 2004, p. 374). Li (2005, pp. 198, 200) proposed that there are two dispositive constructions in the system of VOICE in Chinese. One of which is the $b a \breve{~ c o n s t r u c t i o n ~ r e a l i z i n g ~ t h e ~ " o p e r a t i v e " ~ o p t i o n, ~ a n o t h e r ~ i s ~ t h e ~ b e ̀ i ~ c o n s t r u c t i o n ~ r e a l i z i n g ~ t h e ~ " r e c e p t i v e " ~}$ option, which is similar but not identical to the "passive" in English. They are labeled "operative" and "receptive" instead of "active" and "passive" since there is no distinction between "active" and "passive" verb forms in Chinese as there is in English. Both the bă and bèi constructions are applicable mainly in the transitive material process, and they provide alternative means for making participants the "unmarked" topical theme (see Examples 31-33 in Table 7).

Table 7

The Dispositive bă Constructions

\begin{tabular}{|c|c|c|c|c|}
\hline \multicolumn{5}{|l|}{ Example (31) } \\
\hline$\frac{\text { 把 }}{\underline{B a}}$ & $\begin{array}{l}\text { 那根 钓索 } \\
\text { nagen diaosi } \\
\text { that line }\end{array}$ & $\begin{array}{l}\text { 割 } \\
\text { ge } \\
\text { cut }\end{array}$ & $\begin{array}{l}\text { 断 } \\
\text { duan } \\
\text { away }\end{array}$ & $\begin{array}{l}\text { 了e } \\
L e^{(\mathrm{WU}, 52)}\end{array}$ \\
\hline Dispositive $b \breve{a}$ & Goal/Nominal group & Process (material) & $\begin{array}{l}\text { Post-verb (resultative: } \\
\text { change of state) }\end{array}$ & Aspect (clausal: perfective) \\
\hline \multicolumn{5}{|l|}{ Example (32) } \\
\hline$\frac{\text { 把 }}{\underline{B a}}$ & $\begin{array}{l}\text { 双股的绳子 } \\
\text { shuanggu de shengzi } \\
\text { the double rope }\end{array}$ & $\begin{array}{l}\text { f丁 } \\
d a \\
\text { tied }\end{array}$ & $\begin{array}{l}了 \\
L e\end{array}$ & $\begin{array}{l}\text { 个结子(HAI, 195) } \\
\text { ge jiezi } \\
\text { a knot }\end{array}$ \\
\hline Dispositive $b \breve{a}$ & $\begin{array}{c}\text { Goal 1/Nominal group } \\
1\end{array}$ & Process (material) & Aspect (verbal: perfective) & $\begin{array}{c}\text { Goal 2/Nominal Group } \\
2\end{array}$ \\
\hline \multicolumn{5}{|l|}{ Example (33) } \\
\hline $\begin{array}{l}\text { 他 } \\
\text { ta } \\
\text { he }\end{array}$ & $\frac{\text { 把 }}{B a}$ & \begin{tabular}{|l} 
麻袋 \\
madai \\
sack
\end{tabular} & $\begin{array}{l}\text { 按 } \\
\text { an } \\
\text { adjusted }\end{array}$ & $\begin{array}{l}\text { 平 (HAI, 341) } \\
\text { ping } \\
\text { flat }\end{array}$ \\
\hline Actor & Dispositive $b \breve{a}$ & Goal/Nominal group & Process (material) & $\begin{array}{l}\text { Post-verb (resultative: change of } \\
\text { state) }\end{array}$ \\
\hline
\end{tabular}




\section{Circumstance Preceding Process}

The basic order of elements in the ideational metafunction between English and Chinese is quite similar; the major difference is that in Chinese, most circumstances come before the Process rather than after it as in English (Halliday \& McDonald, 2004, p. 313) (see Examples 34-36 in Table 8).

Table 8

Circumstances Before Processes

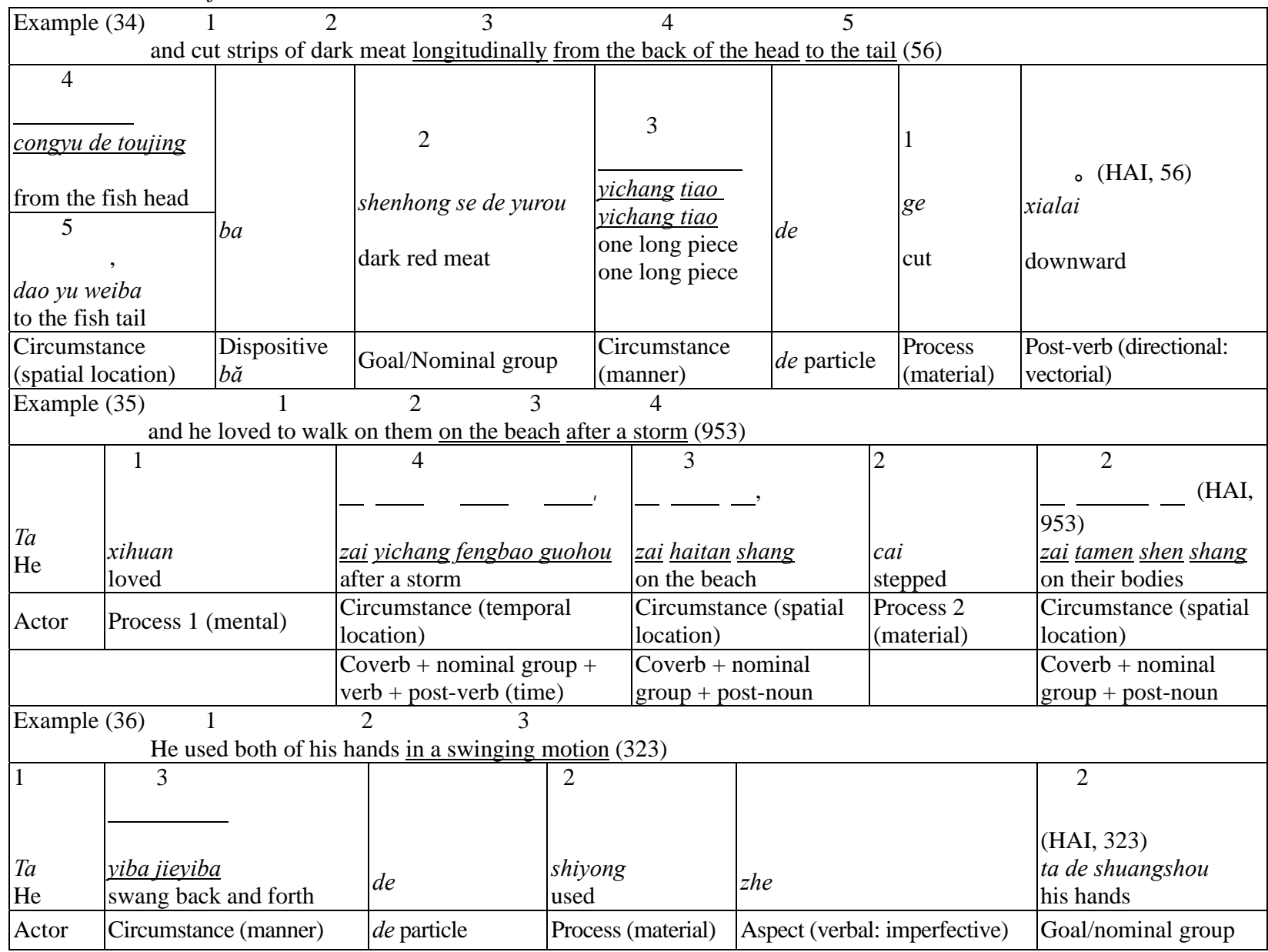

The circumstance preceding the process is most obvious in existential processes, in which the circumstantial element is moved to the initial position of the clause to become typically thematic (Halliday \& McDonald, 2004, p. 355) (see Examples 37-38 in Table 9).

Table 9

Circumstance Before Process in Existential Process

\begin{tabular}{|c|c|c|c|c|c|}
\hline Example (37) & 1 & $\begin{array}{ll}2 & 3\end{array}$ & & & \\
\hline & umulus & gh cirrus above & $\operatorname{im}(1249$ & & \\
\hline $\begin{array}{l}3 \\
\text { 头上 } \\
\text { toushang } \\
\text { above his head }\end{array}$ & \begin{tabular}{|l}
1 \\
有 \\
you \\
there
\end{tabular} & 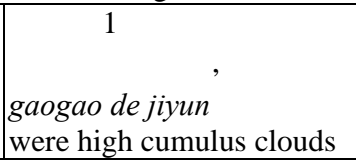 & $\begin{array}{l}\text { 还 } \\
\text { hai } \\
\text { and }\end{array}$ & $\begin{array}{l}\text { 有 } \\
\text { you } \\
\text { have }\end{array}$ & \begin{tabular}{|l}
2 \\
很多的卷云 (HAI, 1249) \\
henduo de juanyun \\
a lot of cirrus
\end{tabular} \\
\hline $\begin{array}{l}\text { Circumstance } \\
\text { (spatial location) }\end{array}$ & Process 1 (existential) & Existent 1 (nominal group) & Adverb & $\begin{array}{l}\text { Process 2 } \\
\text { (existential) }\end{array}$ & Existent 2 (nominal group) \\
\hline
\end{tabular}


(Table 9 continued)

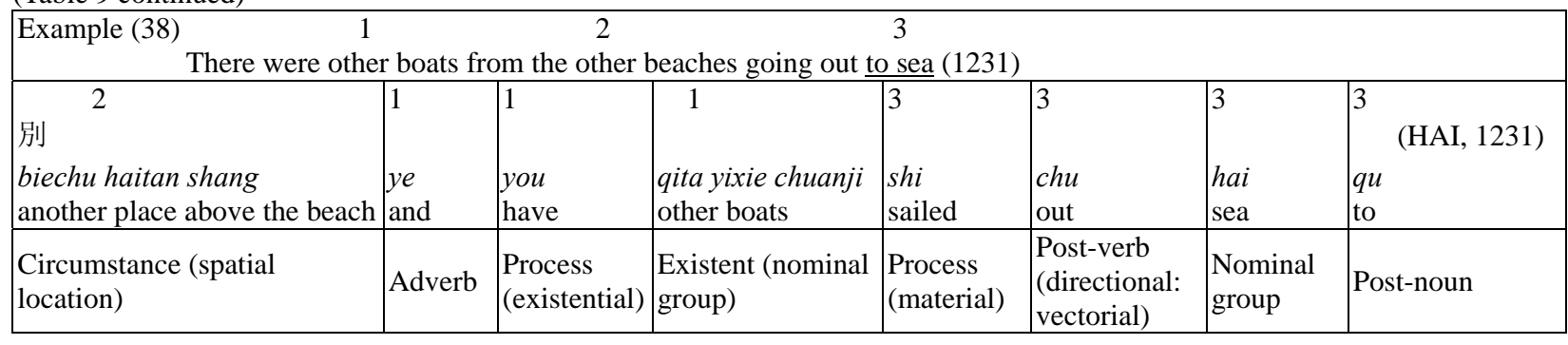

\section{Serial Verbal Construction}

In Chinese, a number of verbal elements can be combined freely with no marking of the relationship between them. They are labeled "serial verbal construction", which makes it difficult to differentiate verbal group from clause and verbal group complex from clause complex (Halliday \& McDonald, 2004, pp. 311, 314). A serial verbal construction normally consists of two or more verbal groups which share the same subject and follow one another without any conjunctions (Yip \& Rimmington, 1997, p. 126).

Table 10

Serial Verbal Constructions

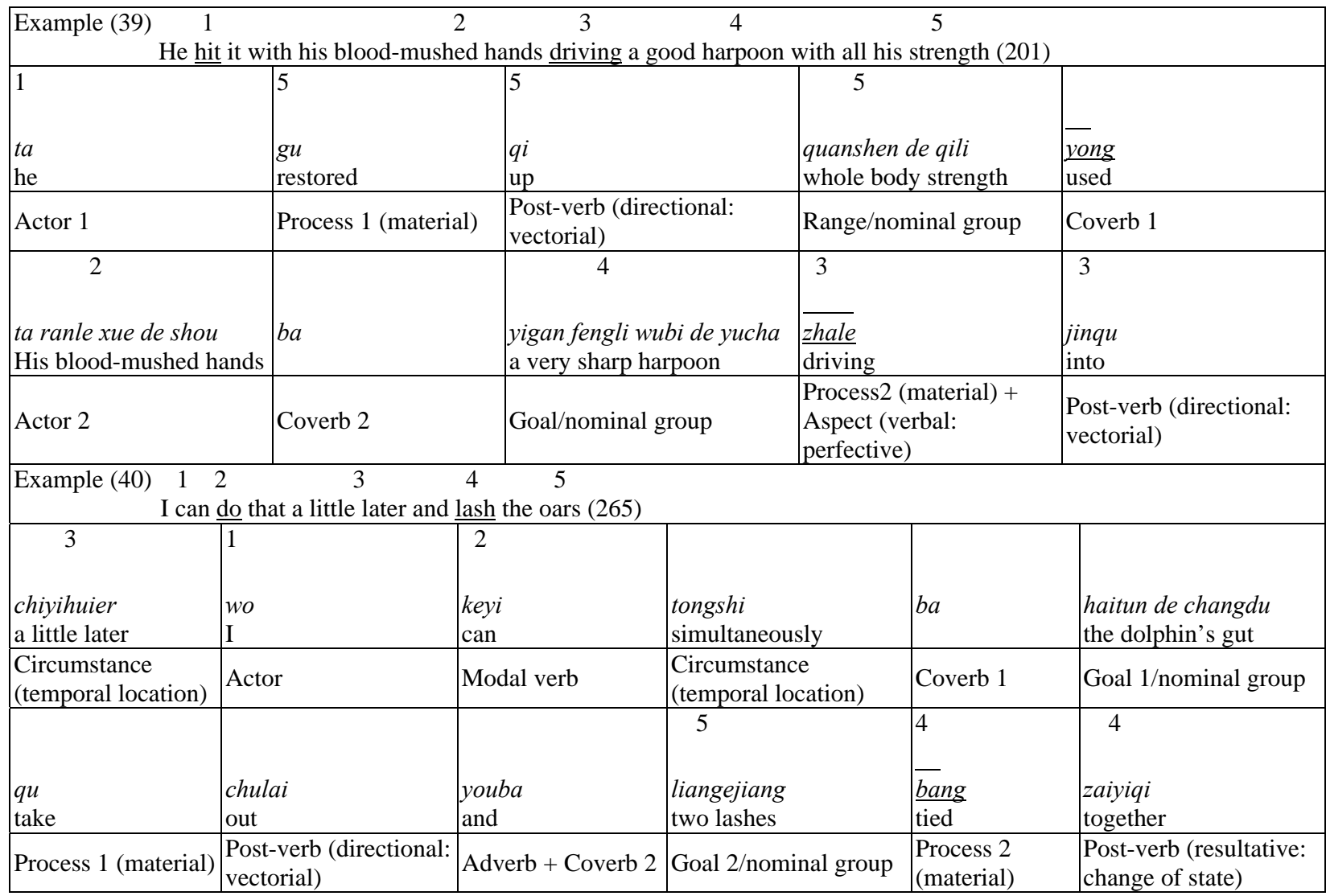

In the above sentence (see Example 39 in Table 10), the minor processes realised by circumstances “with his blood-mushed hands” and "with all his strength” are changed to full processes as verbal groups in Chinese. The sentence is a serial verbal construction containing two material processes—“鼓起” (guqi) and “扎” (zha) —and two coverbs—“用” (yong) and “把” (ba)—strung together to refer to a series of actions 
performed by the old man to harpoon the fish. The relationship between the series of verbal groups is not explicitly indicated.

The above clause (see Example 40 in Table 10) complex is a serial verbal construction containing a modal verb一可以 (keyi), two material processes一取 (qu), 纬 (bang) —and two occurrences of the coverb “把” ( $b a$ ) used consecutively to describe the actions performed by the old man simultaneously to gut the dolphin and lash the oars.

\section{Interpersonal Metafuntion of the Chinese Language}

For the investigation of the applicability of the modality system in Chinese, the author employed Simpson's (1993) point of view model built on the basis of a modal grammar to identify translation shifts in the rendering of a range of deontic, epistemic, and boulomaic modals and generic statements, coupled with DS (direct speech) and FDT (free direct thought) presentation and transitions of modes of point of view. The author compiled a total of 111 clauses (54 deontic modal operators, three generic statements, 46 epistemic, and eight boulomaic modal operators) in the mini corpus of the third day's battle of the old man with the marlin, which accounts for approximately one third of the text studied relative to the corpus of the old man's three-day battle compiled with reference to transitivity. However, for the study of the interpersonal metafunction with reference to the modality system, basically the author conducted the contrastive linguistic analysis more in a wider scope of the "system" rather than the "structure" at the "clause" rank. The author was interested in comparing the clause system of the interpersonal metafunction of the two languages from a paradigmatic perspective with regard to the use of different types of modal operators rather than looking into the clause structures from a syntagmatic aspect as she did in examining the relations of the clause constituents of process, participants, and circumstance for transitivity. Specifically, for the modality system, the author examined how a range of modal operators as used in the source text are instantiated in the given translated text for the realization of modalization (the expression of probability) and modulation (the expression of inclination and obligation). Since the author focused more on a more extensive unit of a sentence or a clause rather than a very delicate description of the lexicogrammtical features of Chinese modality, she observed a high degree of translation correspondence between Chinese and English in the broad system of modality. In the following, the author will provide a brief review of Simpon's model of point of view, then she will present the findings of the translations of the deontic, boulomaic, and epistemic modal operators as identified in the original text. After that, the author will sketch the similarities and differences between English and Chinese with reference to the modulation and modalization systems of the interpersonal metafunction, and explore their applicability to comparative description of Chinese translated texts.

\section{Simpson's (1993) Model of Point of View}

Simpson (1993) broadly divided modality into the deontic, epistemic, and boulomaic systems. Regarding the deontic system, he suggested that deontic modality is the modal system of "duty", expressing a speaker's sense of obligation towards the accomplishment of certain tasks. Deontic modality is often realized by the modal auxiliaries such as "may", "should", and "must", showing varying degrees of commitment attaching to the performance of certain actions, as found in Example (41)-(43) given by Simpson (1990, p. 67):

Example (41) You may leave at ten o'clock. (permission) 
Example (42) You should leave at ten o'clock. (obligation)

Example (43) You must leave at ten o'clock. (requirement)

The above examples illustrate a continuum of commitment of the deontic system ranging from “permission” (see Example 41) through "obligation” (see Example 42) to "requirement” (see Example 43). Deontic modality is concerned with human control over events. It is different from epistemic modality, which mainly deals with the belief of a speaker.

Contrary to deontic modality, epistemic modality expresses a speaker's degree of confidence in the truth of a proposition stated. It is generally realized by the modal auxiliaries such as "could”, "may", "must", "might", and "should", representing a speaker's assessment of the likelihood of events occurring (Simpson, 1993, pp. 48-49). Thus, epistemic modality is also viewed as "probability" modality whereas deontic modality as "obligation" modality (Simpson, 1993, pp. 11). Nevertheless, similar to deontic modality, there is an epistemic modality scale realizing a semantic continuum of probability ranging from uncertainty (1) through probability (2), certainty (3) to logical necessity (4) as illustrated by Examples (44)-(47) provided by HAN (2005, p. 12):

Example (44) They may be there now. (possible but uncertain)

Example (45) They should be there now. (probable)

Example (46) They will be there now. (certain)

Example (47) They must be there now. (logical necessity)

Regarding boulomaic modality, it is closely related to the deontic system, according to Simpson’s (1993) classification of modality. It is concerned with the wishes and desires of a speaker, as revealed in Examples (48)-(50) given by Simpson (1993, p. 48):

Example (48) I hope that you will leave.

Example (49) I wish you'd leave.

Example (50) I regret that you're leaving.

The use of the modal lexical verbs "hope", "wish", and "regret" in the above sentences all express the speaker's wishes and wants in the boulomaic system of modality. Simpson's (1993) classification of modality is slightly different from Halliday's (1994, pp. 356-358). Halliday categorized probability or epistemic modality under modalization, which he associated with propositions (statements and questions), while he grouped obligation or deontic modality together with inclination modality under modulation, which are associated with proposals (offers and commands). In addition, he suggested that there are three "values" of modality—high, median and low—attaching to the modal judgment.

In the study of modality, it is important to notice that the boundaries between deontic and epistemic modalities are often not discrete but tend to overlap since the same modal auxiliaries may express diverse meanings that cut across both deontic and epistemic categories. The notion of the basic indeterminacy of the deontic and epistemic meanings has been observed by Coates (1983), as reviewed by Simpson (1990). Coates (1983) suggested that in the study of deontic and epistemic modalities, there are often indeterminate cases where it is hard to decide which of the two meanings is intended. She provided Example (51) as an illustration (Coates, 1983, p. 16, as cited in Simpson, 1990, p. 68):

Example (51) He must understand that we mean business. 
Coates proposed that the above sentence may include the epistemic meaning that "Surely he understands...” or the deontic meaning that "He will have to understand...” Thus, it appears that there are cases in which both epistemic and deontic meanings are "mutually compatible" and "have undergone a merger" in a specific context (Coates, 1983, p. 16, as cited in Simpson, 1990, p. 68).

Simpson's (1993, pp. 55-81) model of point of view is built on the basis of three types of modality and two categories of narratives contributing to a total of nine polarities of point of view formed by the interaction between the type of modality and the category of narratives employed. In addition, the model includes various modes of speech and thought presentation, which intersect subtly with the nine modes of point of view as indispensable features to look at in a comprehensive study of point of view. In the following, the author will first briefly introduce the two categories of narratives proposed by Simpson, followed by the three types of modality and the nine polarities of point of view as devised in Simpson's point of view model. Since the various modes of speech and thought presentation are not the main focus of this study, and thus they will not be reviewed ${ }^{4}$.

\section{Category A, Category B(N), and Category B(R) Narratives}

In Simpson's model of point of view, there are broadly two categories of narratives-category A narratives and category B narratives. Category A narratives are those narrated in the first person by a participating character within the story. This is viewed as "homodiegetic" narratives with internal focalization (in Genette's (1980) term), where the narrator has restricted omniscience. Category B narratives are those narrated in the third person by a narrator situated outside the story. This corresponds to Genette's "heterodiegetic" narratives with external focalization, where the narrator says less than a character knows. Category B narratives are sub-divided further into two modes, depending on whether events are situated outside or inside the consciousness of a particular character. Narratives told from a viewing position outside the story belong to the $B(N)$ (Narratorial) mode, while narratives that take place within the consciousness of a particular character belong to the R (Reflector) mode. In addition, under each of the categories $A$, category $B(N)$, and category $B(R)$ narratives, there include the "positive shading”, "negative shading", and "neutral shading" modalities to generate a total of nine polarities of point of view $(\mathrm{A}+\mathrm{ve}, \mathrm{A}-\mathrm{ve}, \mathrm{A}$ neutral; $\mathrm{B}(\mathrm{N})+\mathrm{ve}, \mathrm{B}(\mathrm{N})$-ve, $\mathrm{B}(\mathrm{N})$ neutral; $\mathrm{B}(\mathrm{R})+\mathrm{ve}, \mathrm{B}(\mathrm{R})$-ve, and $\mathrm{B}(\mathrm{R})$ neutral). In the following section, the author will introduce the characteristics of the positive shading, negative shading, and neutral shading modalities, and provide a brief overview of the distinctions in meaning among the nine modes of point of view which are contributed by the interaction between the type of modality and the category of narratives employed in a particular mode.

\section{Positive Shading, Negative Shading, and Neutral Shading Modalities}

"Positive shading modality" is characterized by the foregrounding of the deontic and boulomaic systems, verba sentiendi (words denoting thoughts, feelings, and perceptions), evaluative adjectives and adverbs, and generic sentences, highlighting a narrator's duties, obligations, desires, opinions, and judgment, and creating a narrative orientated towards the implied reader with little inferences drawn from the external stimuli. "Negative shading modality”, by contrast, is characterized by the foregrounding of the epistemic and perception modal

\footnotetext{
${ }^{4}$ See Simpson (1993, pp. 21-30) for a comprehensive overview of various modes of speech and thought presentation.
} 
systems, supplemented with generalized “words of estrangement” such as “apparently”, “evidently”, “perhaps”, “as if”, “it seems”, etc.. Moreover, epistemic modal auxiliaries, modal adverbs, and modal lexical verbs such as "I suppose”, "I imagine”, and "I assume” are commonly used to create distancing effects by expressing a character's uncertainty, alienation, and bewilderment. "Neutral shading modality" is an objective style characterized by the complete absence of $\mathrm{N}$ modality, the dominance of unmodalized categorical assertions, few verba sentiendi and evaluative adjectives and adverbs. Rather than presenting qualified opinions and judgments on events and characters, a narrator withholds subjective comments and tells the story primarily through categorical assertions. Thus, the story often comprises sequences of merely physical description with few psychological portraits of characters.

The dominant features of the positive shading, negative shading and neutral shading modalities remain constant across the category $A$, category $B(N)$, and category $B(R)$ narratives; nevertheless, each type of modality interacts differently with the specific category of narratives to give rise to nine polarities of point of view. The three-way interaction among the three types of modality and the three categories of narratives are illustrated in Table 11 in which the peculiar properties of each of the nine modes of point of view are briefly outlined for reference.

Table 11

Simpson's Model of Point of View Built on the Basis of a Modal Grammar (Adapted From Simpson, 1993, p. 75)

\begin{tabular}{|c|c|c|c|}
\hline \multirow[t]{2}{*}{ Type of modality } & Positive shading modality & Negative shading modality & Neutral shading modality \\
\hline & $\begin{array}{l}\text { deontic, boulomaic systems } \\
\text { foregrounded, generics, and } \\
\text { verba sentiendi present }\end{array}$ & $\begin{array}{l}\text { epistemic and perception } \\
\text { systems foregrounded, } \\
\text { supplemented with generalised } \\
\text { "words of estrangement” }\end{array}$ & $\begin{array}{l}\text { unmodalized categorical } \\
\text { assertions dominant, few verba } \\
\text { sentiendi and evaluative } \\
\text { adjectives and adverbs }\end{array}$ \\
\hline \multirow[b]{2}{*}{$\begin{array}{l}\text { Category A narratives } \\
\text { (homodiegetic) }\end{array}$} & $\underline{A+v e}$ & A-ve & A neutral \\
\hline & $\begin{array}{l}\text { first-person narrative via a } \\
\text { participating character. } \\
\text { Canonical example: } \\
\text { Bronte’s Jane Eyre (1847) }\end{array}$ & $\begin{array}{l}\text { first-person narrative via a } \\
\text { participating character, } \\
\text { creating distancing effect, } \\
\text { alienation, and bewilderment. } \\
\text { Canonical example: } \\
\text { Beckett’s Molly (1950) }\end{array}$ & $\begin{array}{l}\text { first-person narrative via a } \\
\text { participating character, flat, } \\
\text { journalistic style, } \\
\text { characteristic of “hard-boiled” } \\
\text { detective fiction. } \\
\text { For example: Chandler's } \\
\text { Farewell, My Lovely (1940) }\end{array}$ \\
\hline \multirow[b]{2}{*}{$\begin{array}{l}\text { Category B narratives } \\
\text { (heterodiegetic) } \\
\text { N mode }\end{array}$} & $\underline{B}(\mathrm{~N})+\mathrm{ve}$ & $\mathrm{B}(\mathrm{N})$-ve & $\underline{\mathrm{B}(\mathrm{N}) \text { neutral }}$ \\
\hline & $\begin{array}{l}\text { third-person narrative via a } \\
\text { non-participating narrator, } \\
\text { offering opinions and } \\
\text { judgements. } \\
\text { For example: } \\
\text { Conrad's The Secret Agent } \\
\text { (1907) }\end{array}$ & $\begin{array}{l}\text { third-person narrative via a } \\
\text { non-participating narrator, } \\
\text { creating distancing effect, } \\
\text { alienation and bewilderment. } \\
\text { Canonical example: } \\
\text { Kafka's The Trial (1925) }\end{array}$ & $\begin{array}{l}\text { third-person narrative via a } \\
\text { non-participating narrator, } \\
\text { refusing access to thoughts } \\
\text { and characters. } \\
\text { Canonical example: } \\
\text { Hemingway’s The Killers } \\
(1928)\end{array}$ \\
\hline \multirow[b]{2}{*}{$\begin{array}{l}\text { Category B narratives } \\
\text { (heterodiegetic) } \\
\text { R mode }\end{array}$} & $\mathrm{B}(\mathrm{R})+\mathrm{ve}$ & B(R)-ve & $\mathrm{B}(\mathrm{R})$ neutral \\
\hline & $\begin{array}{l}\text { third-person narrative located } \\
\text { within viewing position of } \\
\text { character, offering their } \\
\text { opinions and judgments. } \\
\text { Canonical example: } \\
\text { James's The Ambassadors } \\
\text { (1903) }\end{array}$ & $\begin{array}{l}\text { third-person narrative, } \\
\text { "estrangement” situated in the } \\
\text { mind of character: hence } \\
\text { double focalization, distal } \\
\text { deictics used to suggest spatial } \\
\text { distance between viewer and } \\
\text { object. } \\
\text { For example: Kafka's The } \\
\text { Trial (1925) }\end{array}$ & $\begin{array}{l}\text { third-person narrative situated } \\
\text { in viewing position of } \\
\text { character, evaluative } \\
\text { modalities still withheld and } \\
\text { categorical assertions } \\
\text { dominant. } \\
\text { For example: Flaubert's } \\
\text { Madame Bovary (1856) }\end{array}$ \\
\hline
\end{tabular}




\section{Findings of the Translations of Modality}

The author found that Simpson's model of point of view, overall, works well for the analysis of Chinese texts as it does for the English original text, including the range of modals and speech and thought presentation, and the similarities appear to be more striking than the differences between the two languages in the modality system. For the various types of modals used in the English original, the author found their similar counterparts in the four Chinese translations. Moreover, the use of the reporting clause such as "he said" in speech presentation and "he thought" in thought presentation also have their close parallels in Chinese. The whole multilayered point of view model that integrates different types of modals, narrative point of view, and speech and thought presentation as an analytical framework for discovering attitude in translations is demonstrated to be effective and applicable to Chinese translated texts. In Tables 12-13, the author outlined the corresponding translations of the lists of deontic, boulomaic, and epistemic modal operators uncovered in the mini corpus of The Old Man and the Sea compiled and their frequencies of occurrence as found in the four translations. After that the author will provide a sketch of the similarities and differences between English and Chinese in the modality system.

Table 12

The Chinese Translations of the Deontic and Boulomaic Modal Operators Uncovered in the Mini Corpus of The Old Man and the Sea

\begin{tabular}{|c|c|c|c|c|c|}
\hline \multirow{3}{*}{$\begin{array}{l}\text { Must/Mustn’t } \\
\text { (No. of occurrence) } \\
20\end{array}$} & \begin{tabular}{|l} 
一定 (yiding) \\
11
\end{tabular} & $\begin{array}{l}\text { 必须 (bixu) } \\
9\end{array}$ & $\begin{array}{l}\text { 得 }(d e) \\
14\end{array}$ & $\begin{array}{l}\text { 可不能 (kebuneng) } \\
4\end{array}$ & $\begin{array}{l}\text { (应)该 }(\mathrm{gai}) \\
5\end{array}$ \\
\hline & 决不要 (juebuyao) & $\begin{array}{l}\text { 就 (jiu) } \\
1\end{array}$ & 要 $(y a o)$ & $\begin{array}{l}\text { 准是 (zhunshi) } \\
1\end{array}$ & $\begin{array}{l}\text { 不该 (bu gai) } \\
1\end{array}$ \\
\hline & $\begin{array}{l}\text { 尽可能 (jinkeneng) } \\
2\end{array}$ & & & & \\
\hline \multirow{2}{*}{$\begin{array}{l}\text { Can/Could (not) } \\
\text { (No. of occurrence) } \\
14\end{array}$} & $\begin{array}{l}\text { 可以 } \\
(k e y i) \\
9\end{array}$ & $\begin{array}{l}\text { (可) (不) 能 } \\
(k e)(b u) \text { (neng) } \\
10\end{array}$ & \begin{tabular}{|l} 
得 \\
$(d e)$ \\
4
\end{tabular} & $\begin{array}{l}\text { 必须 } \\
(\text { bixu }) \\
1 \\
\end{array}$ & $\begin{array}{l}\text { 该 } \\
\text { (gai) } \\
1\end{array}$ \\
\hline & $\begin{array}{l}(\text { 不)会 } \\
(b u)(h u i) \\
6\end{array}$ & $\begin{array}{l}\text { (只) (准) 能 } \\
(z h i) \\
6\end{array}$ & $\begin{array}{l}\text { 只宜 } \\
\text { (zhiyi) } \\
1\end{array}$ & \begin{tabular}{|l} 
做得到 \\
(zuodedao) \\
1
\end{tabular} & $\begin{array}{l}\text { 尽 } \\
(\text { jin }) \\
2 \\
\end{array}$ \\
\hline \multirow{3}{*}{$\begin{array}{l}\text { Will/Would } \\
\text { (No. of occurrence) } \\
20\end{array}$} & $\begin{array}{l}\text { (还)要 (hai) yao } \\
13\end{array}$ & $\begin{array}{l}\text { (也)会 }(y e) \text { (hui) } \\
11\end{array}$ & \begin{tabular}{|l} 
还得 (haide) \\
1
\end{tabular} & $\begin{array}{l}\text { (就)要 (jiu) (jiuyao) } \\
11\end{array}$ & $\begin{array}{l}\text { (就)能 (jiu) (neng) } \\
6\end{array}$ \\
\hline & \begin{tabular}{|l} 
就得 (jiude) \\
1 \\
\end{tabular} & \begin{tabular}{|l} 
就是 (jiushi) \\
2 \\
\end{tabular} & \begin{tabular}{|l} 
就行 (jiucheng) \\
1
\end{tabular} & \begin{tabular}{|l} 
倒是 (daoshi) \\
2
\end{tabular} & $\begin{array}{l}\text { 一定 (yiding) } \\
2\end{array}$ \\
\hline & $\begin{array}{l}\text { (那) 就 (na) (jiu) } \\
4\end{array}$ & $\begin{array}{l}\text { 还会 (haihui) } \\
2\end{array}$ & $\begin{array}{l}\text { 只要 (zhiyao) } \\
4\end{array}$ & 倒想 (daoxiang) & \\
\hline \multirow{3}{*}{$\begin{array}{l}\text { Wish } \\
\text { (No. of occurrence) } \\
8\end{array}$} & $\begin{array}{l}\text { 想 } \\
(\text { xiang) } \\
3 \\
\end{array}$ & $\begin{array}{l}\text { 但愿 } \\
\text { (danyuan) } \\
6 \\
\end{array}$ & \begin{tabular}{|l}
$($ (倒真)希望 \\
(zhenxiwang) \\
3
\end{tabular} & $\begin{array}{l}\left(\begin{array}{l}(\text { 倒)情愿 } \\
\text { (qingyuan) } \\
2\end{array}\right. \\
\end{array}$ & $\begin{array}{l}\text { 真盼望 } \\
(\text { zhenpanwang) } \\
1\end{array}$ \\
\hline & $\begin{array}{l}\text { 最好 } \\
(\text { zuihao }) \\
1 \\
\end{array}$ & \begin{tabular}{|l} 
还不如 \\
$($ haiburu) \\
1 \\
\end{tabular} & \begin{tabular}{|l} 
倒情愿 \\
$($ daoqingyuan $)$ \\
2 \\
\end{tabular} & $\begin{array}{l}\text { 渴望 } \\
(\text { kewang) } \\
1\end{array}$ & $\begin{array}{l}\text { 巴望的事儿 } \\
\text { (bawangdeshiyi) } \\
1\end{array}$ \\
\hline & $\begin{array}{l}\text { 多好 } \\
(\text { duohao }) \\
1\end{array}$ & $\begin{array}{l}\text { 就好 } \\
\text { (jiuhao) } \\
1 \\
\end{array}$ & \begin{tabular}{|l} 
想要 \\
$($ xiangyao) \\
2 \\
\end{tabular} & $\begin{array}{l}\text { 我的愿望 } \\
\text { (wodeyuanwang) } \\
1\end{array}$ & \\
\hline
\end{tabular}


Table 13

The Chinese Translations of the Major Epistemic Modal Operators Uncovered in the Mini Corpus of The Old Man and the Sea

\begin{tabular}{|c|c|c|c|c|c|}
\hline \multirow{2}{*}{$\begin{array}{l}\text { Perhaps } \\
\text { (No. of occurrence) } \\
6\end{array}$} & $\begin{array}{l}\text { 也许(是) } \\
(\text { yexue }) \\
14\end{array}$ & $\begin{array}{l}\text { 可能 } \\
\text { (yexukeneng) } \\
1\end{array}$ & \begin{tabular}{|l|} 
没准儿 \\
(meizhuner) \\
1
\end{tabular} & \begin{tabular}{|l} 
怕也未必 \\
(payeweibi) \\
1
\end{tabular} & \begin{tabular}{|l} 
或许 \\
$($ huoxu $)$ \\
2 \\
\end{tabular} \\
\hline & $\begin{array}{l}\text { 说不定 } \\
\text { (shuobuding) } \\
1\end{array}$ & $\begin{array}{l}\text { 我想是 } \\
(\text { woxiangshi }) \\
2\end{array}$ & & & \\
\hline \multirow{2}{*}{$\begin{array}{l}\text { May } \\
\text { (No. of occurrence) } \\
4\end{array}$} & $\begin{array}{l}\text { 就会 (jiuhui) } \\
1\end{array}$ & 也许会 (yexuhui) & $\begin{array}{l}\text { 该是 (gaishi) } \\
1\end{array}$ & $\begin{array}{l}\text { 还可 (haike) } \\
1\end{array}$ & \begin{tabular}{|l} 
会 $(h u i)$ \\
2
\end{tabular} \\
\hline & $\begin{array}{l}\text { 也许能 (yexuneng) } \\
1\end{array}$ & $\begin{array}{l}\text { 还会 (haihui) } \\
1\end{array}$ & $\begin{array}{l}\text { 可以 (keyi) } \\
1\end{array}$ & & \\
\hline \multirow{2}{*}{$\begin{array}{l}\text { Maybe } \\
\text { (No. of occurrence) } \\
5\end{array}$} & $\begin{array}{l}\text { 也许 } \\
(\text { yexu }) \\
14\end{array}$ & \begin{tabular}{|l} 
作兴 \\
$($ zuoxing) \\
2
\end{tabular} & $\begin{array}{l}\text { 或许 } \\
(\text { huoxu }) \\
2\end{array}$ & $\begin{array}{l}\text { 没准儿 } \\
\text { (meizhuner) } \\
1\end{array}$ & $\begin{array}{l}\text { 说不定 } \\
\text { (shuobuding) } \\
3\end{array}$ \\
\hline & $\begin{array}{l}\text { 也许可以 } \\
\text { (yexukeyi) } \\
1 \\
\end{array}$ & $\begin{array}{l}\text { 许能 } \\
(\text { xuneng) } \\
1\end{array}$ & & & \\
\hline $\begin{array}{l}\text { Will } \\
\text { (No. of occurrence) } \\
4\end{array}$ & $\begin{array}{l}\text { 就会 (jiuhui) } \\
1\end{array}$ & 要 $(y a o)$ & $\begin{array}{l}\text { 还要 (haiyao) } \\
2\end{array}$ & & \\
\hline $\begin{array}{l}\text { Would rather } \\
\text { (No. of occurrence) } \\
2\end{array}$ & $\begin{array}{l}\text { 倒希望 } \\
(\text { daoxiwang) } \\
1 \\
\end{array}$ & $\begin{array}{l}\text { 可是情愿 } \\
\text { (keshiqingyuan) } \\
1 \\
\end{array}$ & \begin{tabular}{|l} 
倒不明白 \\
$($ daobumingbai $)$ \\
1
\end{tabular} & $\begin{array}{l}\text { 我可情愿 } \\
\text { (wokeqingyuan) } \\
1\end{array}$ & $\begin{array}{l}\text { 它许会 } \\
(\text { taxuhui }) \\
1 \\
\end{array}$ \\
\hline $\begin{array}{l}\text { I wonder } \\
\text { (No. of occurrence) } \\
3\end{array}$ & \begin{tabular}{|l} 
我不懂 \\
(wobudong) \\
2 \\
\end{tabular} & \begin{tabular}{|l} 
不知道 \\
$($ buzhidao $)$ \\
5 \\
\end{tabular} & \begin{tabular}{|l} 
不明白 \\
$($ bumingbai) \\
2 \\
\end{tabular} & \begin{tabular}{|l} 
我不晓得 \\
$($ wobuxiaode) \\
2 \\
\end{tabular} & $\begin{array}{l}\text { 不知 } \\
(b u z h i) \\
1\end{array}$ \\
\hline $\begin{array}{l}\text { I suppose } \\
\text { (No. of occurrence) } \\
1\end{array}$ & \begin{tabular}{|l} 
我猜想 \\
(wocaixiang) \\
1 \\
\end{tabular} & \begin{tabular}{|l} 
我看该是 \\
(wokangaishi) \\
1
\end{tabular} & $\begin{array}{l}\text { 我想是 } \\
(\text { woxiang) } \\
1 \\
\end{array}$ & $\begin{array}{l}\text { 我猜想一定是 } \\
\text { (wocaixiang } \\
\text { yidingshi) } \\
1\end{array}$ & \\
\hline $\begin{array}{l}\text { Should have } \\
\text { (No. of occurrence) } \\
2\end{array}$ & $\begin{array}{l}\text { 应该 (yinggai) } \\
6\end{array}$ & $\begin{array}{l}\text { 原该 (yuangai) } \\
2\end{array}$ & $\begin{array}{l}\text { 总该 (zonggai) } \\
1\end{array}$ & 也会 (yehui) & $\begin{array}{l}\text { 就好 (jiuhao) } \\
2\end{array}$ \\
\hline \multirow{2}{*}{$\begin{array}{l}\text { Might have } \\
\text { (No. of occurrence) } \\
1\end{array}$} & $\begin{array}{l}\text { 也许 } \\
(\text { yexu }) \\
2 \\
\end{array}$ & \begin{tabular}{|l} 
说不定 \\
(shuobuding) \\
1 \\
\end{tabular} & $\begin{array}{l}\text { 那也可能 } \\
\text { (nayekeneng) } \\
1 \\
\end{array}$ & \begin{tabular}{|l} 
就会 \\
$($ jiuhui $)$ \\
1
\end{tabular} & \begin{tabular}{|l} 
就能 \\
$($ jiuneng) \\
1 \\
\end{tabular} \\
\hline & $\begin{array}{l}\text { 你怎么 (nizenmo) } \\
1\end{array}$ & $\begin{array}{l}\text { 可要是 (keyaoshi) } \\
1\end{array}$ & & & \\
\hline $\begin{array}{l}\text { I do not know (No } \\
\text { of occurrence) } \\
1\end{array}$ & \begin{tabular}{|l} 
我摸不透 \\
$($ womobutou $)$ \\
2
\end{tabular} & $\begin{array}{l}\text { 我弄不懂 } \\
\text { (wonongbudong) } \\
2\end{array}$ & $\begin{array}{l}\text { 我不知道 } \\
(\text { wobuzhidao }) \\
2\end{array}$ & \begin{tabular}{|l} 
真不知道 \\
$($ zhenbuzhidao $)$ \\
2
\end{tabular} & \\
\hline $\begin{array}{l}\text { I cannot know } \\
\text { (No. of occurrence) } \\
2\end{array}$ & $\begin{array}{l}\text { 我可没法知道 } \\
(\text { woke meifa zhidao) } \\
1\end{array}$ & $\begin{array}{l}\text { 我没法知道 } \\
(\text { wo meifa zhidao }) \\
1\end{array}$ & \begin{tabular}{|l|} 
我可没法儿知道 \\
$($ wo meifaer zhidao $)$ \\
1
\end{tabular} & & \\
\hline $\begin{array}{l}\text { I am not sure } \\
\text { (No. of occurrence) } \\
3\end{array}$ & \begin{tabular}{|l|} 
我不怎么相信 \\
(wobuzenmo \\
xiangxin) \\
1 \\
\end{tabular} & \begin{tabular}{|l|} 
也说不准 \\
(yeshuobuzhun) \\
1 \\
\end{tabular} & $\begin{array}{l}\text { 我不相信 } \\
\text { (wobuxiangxin) } \\
1 \\
\end{array}$ & \begin{tabular}{|l|} 
我也不怎么相信 \\
(woyebuzenmoxian \\
gxin) \\
1 \\
\end{tabular} & \\
\hline $\begin{array}{l}\text { But I am sure he } \\
\text { would have (No. of } \\
\text { occurrence) } \\
2\end{array}$ & $\begin{array}{l}\text { 可是我相信 } \\
\text { (keshiwoxiangxin) } \\
1\end{array}$ & $\begin{array}{l}\text { 也会 } \\
(\text { yehui }) \\
2\end{array}$ & $\begin{array}{l}\text { 他肯定相信 } \\
\text { (takendingxiangxin) } \\
1\end{array}$ & \begin{tabular}{|l} 
不过他一定会 \\
有信心 \\
(buguotayidinghui \\
youxinxin) \\
1
\end{tabular} & \\
\hline
\end{tabular}


(Table 13 continued)

\begin{tabular}{|c|c|c|c|c|c|}
\hline $\begin{array}{l}\text { What he could do } \\
\text { (No. of occurrence) } \\
2\end{array}$ & \begin{tabular}{|l} 
它会怎么样去 \\
(tahuizenmoyangqu) \\
1
\end{tabular} & \begin{tabular}{|l|} 
会怎么 \\
(huizenmo) \\
1 \\
\end{tabular} & & & \\
\hline $\begin{array}{l}\text { I should have } \\
\text { (No. of occurrence) } \\
1\end{array}$ & $\begin{array}{l}\text { 我应该 (woyinggai) } \\
1\end{array}$ & $\begin{array}{l}\text { 我本该 (wobengai) } \\
2\end{array}$ & $\begin{array}{l}\text { 我可以 (wokeyi) } \\
1\end{array}$ & & \\
\hline $\begin{array}{l}\text { But if I had, and } \\
\text { could have } \\
\text { (No. of occurrence) } \\
6\end{array}$ & $\begin{array}{l}\text { 要是我能够 } \\
\text { (yaoshiwonenggou) } \\
1\end{array}$ & $\begin{array}{l}\text { 如果就能 } \\
\text { (ruguojiuneng) } \\
1\end{array}$ & $\begin{array}{l}\text { 如果该是 } \\
\text { (ruguogaishi) } \\
1\end{array}$ & $\begin{array}{l}\text { 要是 (能) } \\
\text { (yaoshi) (neng) } \\
1\end{array}$ & $\begin{array}{l}\text { 那是多棒 } \\
\text { (nashiduobang) } \\
1\end{array}$ \\
\hline $\begin{array}{l}\text { What will you do } \\
\text { (No. of occurrence) } \\
1\end{array}$ & $\begin{array}{l}\text { 你该怎么办？ } \\
\text { (nigaizenmoban) } \\
2\end{array}$ & $\begin{array}{l}\text { 你怎么对付呢？ } \\
\text { (nizenmoduifune) } \\
1\end{array}$ & $\begin{array}{l}\text { 你能做些什么? } \\
\text { (ninengzuoxie } \\
\text { shenmo) } \\
1 \\
\end{array}$ & & \\
\hline $\begin{array}{l}\text { Could I buy (No. of } \\
\text { occurrence) } \\
3\end{array}$ & \begin{tabular}{|l} 
能够用 \\
(nenggouyong) \\
1
\end{tabular} & \begin{tabular}{|l|} 
能用 \\
(nengyong) \\
2 \\
\end{tabular} & \begin{tabular}{|l} 
可以 \\
(keyi) \\
1 \\
\end{tabular} & & \\
\hline $\begin{array}{l}\text { You might (No. of } \\
\text { occurrence) } \\
3\end{array}$ & $\begin{array}{l}\text { 可以 (keyi) } \\
2\end{array}$ & $\begin{array}{l}\text { 也许能 (yexuneng) } \\
1\end{array}$ & & & \\
\hline $\begin{array}{l}\text { Will probably (No. } \\
\text { of occurrence) } \\
2\end{array}$ & $\begin{array}{l}\text { 也许它們还有 } \\
\text { (yexutamenhaiyao) } \\
1\end{array}$ & $\begin{array}{l}\text { 也许還会 } \\
\text { (yexuehaihui) } \\
1\end{array}$ & $\begin{array}{l}\text { 可能 } \\
\text { (keneng) } \\
1\end{array}$ & $\begin{array}{l}\text { 大概还要 } \\
\text { (daigaihaiyao) } \\
1\end{array}$ & \\
\hline $\begin{array}{l}\text { What can (No. of } \\
\text { occurrence) } \\
2\end{array}$ & \begin{tabular}{|l} 
怎么去 \\
(zenmoqu) \\
1
\end{tabular} & $\begin{array}{l}\text { 怎么能 } \\
\text { (zenmoneng) } \\
1\end{array}$ & $\begin{array}{l}\text { 怎么 } \\
(\text { zenmo) } \\
2\end{array}$ & & \\
\hline
\end{tabular}

According to Halliday and McDonald (2004, p. 339), in Chinese as in English, the system of modality comprises modalization (the expression of probability) and modulation (the expression of inclination and obligation). There is a continuum of values in the realms of modalization and modulation in both languages. In Simpson's (1993) point of view model, modulation (modals expressing inclination, ability, and duties) together with the boulomaic system expressing desires and wishes are categorized under "positive shading modality”, while modalization (probability modals) coupled with perception modals, supplemented with generalized "words of estrangement" such as "apparently", “evidently”, "perhaps”, “as if”, and "it seems” are grouped under negative shading modality. Overall, the author found English and Chinese share many similarities in the modality system. In both languages, modality can be expressed by modal verbs (may, must, will, shall, etc.); modal adverbs (probably, perhaps, surely, etc.); and verbs of knowledge, prediction, or evaluation (seem, believe, guess, etc.). Moreover, both languages share a semantic scale in the notions of probability, inclination, and obligation, ranging from "high", "median" to "low" values according to Halliday's (1994, p. 357) classification of modality.

Nevertheless, the major difference between English and Chinese with regard to modal verbs is that in English, all English modal verbs except "shall" can express both modality and modulation (ZHU, 1996, p. 206), whereas in Chinese, mainly “会” (hui) and “要” (yao) can be used respectively to express low and median degrees of probability other than obligation (Halliday \& McDonald, 2004, p. 339), and there are only a few other modals that can be used for both modality and modulation (ZHU, 1996, p. 208). In addition, it is worthy of attention that the boundaries between deontic and epistemic modalities are not always clear cut, but tend to overlap. This is applicable to both languages as revealed in the original text and the four 
translations of the modals as uncovered in the parallel corpus of modality. In compiling the mini parallel corpus of modality in this study, for the sake of convenience and coherence in counting the frequencies of a variety of modal operators used, the author put the modal verbs such as "must", "can/could", and "will/would" all under the deontic category, but in fact, some of them cut across the deontic and epistemic categories and can be used to convey both deontic and epistemic meanings; for example the modal "must" in "I must hold all I can" (1278) is used in a deontic sense to express the old man’s deontic duty/ability to catch the fish. But the modal "must" can also be used to mean the old man's assessment of the possibility of the events occurring such as "they must have taken a quarter of him and of the best meat" (1293). It depends on the context to differentiate the meaning of the modal. In some cases, the same modal has undergone a merger and may have two possible meanings, allowing different interpretations. This is revealed in different translations of the modal "will” in the clause- “Then in two or three turns more I will have him” (1315), in which HAI (1957) translated “will” into “我就要 (jiuyao) 把它捉住啦”, conveying a sense of deontic duty; while WU (1987) translated it into “我就能 (jiuneng) 收服它”, and LI (1987) translated it as “就能 (jiuneng) 见着魚”, which can be interpreted as the epistemic probability of the man hitting the fish. Likewise, the modal "will” in "This time I'll pull him over" (1318) is interpreted differently by different translators-HAI (1957) translated it into “我会 (hui) 把它曳过来的”-expressing the old man's assessment of his probability of hooking the fish; while ZHAO (1987) translated it into “我要 (yao) 把它拉 过来”, expressing the old man's self-command to catch the fish.

As mentioned above pointed out by ZHU (1996, p. 206), there are only a few modal verbs among the Chinese modals that can be used for both modalization and modulation, while English modals except "shall" can express both modalization and modulation. Therefore, it is worthwhile to look into a proper categorization of a variety of modals for the realization of the networks of modality and modulation in Chinese. ZHU (1996, pp. 189-205) compared the systems of modalization and modulation in English and Chinese from Halliday's systemic-functional approach. Based on the information he introduced, the author compiled a list of the modal operators of probability (see Table 14) and that of ability, inclination and obligation (see Table 15) as outlined below. Moreover, ZHU (1996, p. 208) attempted to match the English modals with their counterparts in Chinese as listed in Table 16. They serve as a useful reference for the study of the modality system in Chinese and research in contrastive linguistics.

Table 14

Modalization in Chinese (Realisation of Probability)

\begin{tabular}{|l|l|}
\hline Value & Modal verbs \\
\hline Low & 可能 (keneng can) 会 (hui can) \\
\hline High & 该 (gai should) \\
\hline & Modal adverbs \\
\hline High & 一定 (yiding must) 肯定 (kending must) 必定 (biding must) 准 (zhun must) \\
\hline Median & 大概 (dagai probably) 多半 (duoban probably) \\
\hline Low & 也许 (yexu perhaps) 或许 ( huoxu perhaps) \\
\hline & Full verbs of knowledge, prediction, and evaluation \\
\hline & 相信 (xiangxin believe) 估计 (guji estimate) 看 (kan think) 想 (xiang reckon) \\
\hline
\end{tabular}


Table 15

Modulation in Chinese (Realisation of Ability, Inclination, and Obligation)

\begin{tabular}{|l|l|}
\hline Value & Modal verbs of ability \\
\hline & 能 (neng can) 能够 (nenggou can) 可以 (keyi can) 会 (hui can) \\
\hline & Modal verbs of inclination \\
\hline High (insistence) & 要 (yao will) \\
\hline Median (intention) & 想 (xiang wish) \\
\hline Low (willingness) & \begin{tabular}{l} 
愿意 (yuanyi will) 肯 (ken will) \\
\hline
\end{tabular} Modal adverbs of inclination \\
\hline High & 一定 (yiding must) 偏 (pian must) 非 (fei must) \\
\hline High (compulsion) & Modal verbs of obligation \\
\hline Median (expectation) & $\begin{array}{l}\text { 要 (yao must) 必须 (bixu must) 得 (dei must, the most colloquial form) } \\
\text { 该 (gai should) }\end{array}$ \\
\hline Low (permission) & $\begin{array}{l}\text { 可以 (keyi may) 许 ( } x u \text { allow) 准 (zhun allow) 得 (de) should—always used in its negative } \\
\text { form—“不得” ( bude) should not—to indicate prohibition }\end{array}$ \\
\hline & Full verbs and nouns of obligation \\
\hline & $\begin{array}{l}\text { Verbs such as 要求 (yaoqiu require) 强迫 (qiang po compel) 让 (rang let) 允许 (yunxu permit); } \\
\text { nouns such as 义务 (yiwu duty) 责任 (zeren responsibility) 许可 (xuke permission) }\end{array}$ \\
\hline
\end{tabular}

Table 16

Correspondence Between English and Chinese Modals (Adapted From ZHU, 1996, p. 208)

\begin{tabular}{|c|c|c|}
\hline English modals & Categories of modals & Chinese modals \\
\hline \multirow{4}{*}{ Can/Could } & Probability & 可能 (keneng) \\
\hline & Ability & 能够 (neng gou) \\
\hline & Ability & 可以 (keyi) \\
\hline & Probability/Ability & 会 $(h u i)$ \\
\hline \multirow{4}{*}{ Will/Would } & Inclination & 想 (xiang) \\
\hline & Inclination & 愿意 (yuanyi) \\
\hline & Inclination & 肯 $(k e n)$ \\
\hline & Inclination & 要 $(y a o)$ \\
\hline \multirow[b]{2}{*}{ Shall } & Inclination & 想 (xiang) \\
\hline & Inclination & 愿意 (yuanyi) \\
\hline \multirow{4}{*}{ May/Might } & Probability & 可能 (keneng) \\
\hline & Permission & 可以 (keyi) \\
\hline & Permission & 许 $(x u)$ \\
\hline & Permission & 准 (zhun) \\
\hline \multirow{3}{*}{ Should/Ought to } & Probability/Expectation & 该 (gai) \\
\hline & Probability/Expectation & 应该 (yinggai) \\
\hline & Probability/Expectation & 应当 (yingdang) \\
\hline \multirow{3}{*}{ Must } & Compulsion & 必须 (bixu) \\
\hline & Compulsion & 要 $(y a o)$ \\
\hline & Compulsion & 得 $(d e i)$ \\
\hline
\end{tabular}


According to ZHU's (1996) categorization of the modalization and modulation modals as outlined in Tables 14-16, the few modals that can be used for both modality and modulation are “会” (hui can)”, “该” (gai should)”, “一定” (yiding must), and “准” (zhun must, allow). Since compared to English in which all modal verbs except "shall” can express both modality and modulation (ZHU, 1996, p. 208), there is a relatively fixed set of modals used particularly for the realization of modalization and modulation, the author would suggest that Simpson's (1993) model of point of view could be refined better by including a more defined set of modal operators each under the categories of positive shading modality and negative shading modality for the description of Chinese translated texts. Though the lists of both categories of modals are not exhaustive, they are useful reference and make the SFG model more serviceable for the categorization of translation shifts in Chinese texts. Nevertheless, it is worthy of attention as mentioned above that the boundaries between deontic and epistemic modalities are not clear cut but tend to overlap. The same modal can be interpreted differently from different angles, and carry both the deontic and the epistemic meanings. Moreover, Simpson's model of point of view built on the basis of a modal grammar is basically English oriented. While it works effectively for the investigation of narrative point of view for English texts, it should better be adapted according to the typical characteristics of the Chinese modality system for the linguistic description of Chinese translated texts, particularly for corpus-based translation research which usually aims to investigate selected lexical items for the identification of linguistic patterns of choices. Based on ZHU's (1996, pp. 189-205) categorization of modalization and modulation in Chinese as outlined in Table 14 together with the findings of the translations of a variety of modals collected in this study, the author proposed a list of modal operators that can be included in Simpson's point of view model under the categories of positive shading modality and negative shading modality, which interact with the categories of narrative for the generation of the nine polarities of point of view. The two major types of modals are outlined in Tables 17-18.

Table 17

Positive Shading Modality in Chinese System With Reference to Simpson's Point of View Model (1993)

\begin{tabular}{|l|l|}
\hline $\begin{array}{l}\text { Type of modality } \\
\text { (Value) }\end{array}$ & $\begin{array}{l}\text { Positive shading modality } \\
\text { deontic, boulomaic systems foregrounded, generics, and verba sentiendi present }\end{array}$ \\
\hline Modal verbs of ability & $\begin{array}{l}\text { 能 (neng can) 能够 (nenggou can) } \\
\text { 可以 (keyi can) 会 (hui can) }\end{array}$ \\
\hline $\begin{array}{l}\text { Modal verbs of inclination } \\
\text { (high, insistence) }\end{array}$ & (还) 要 (yao will) \\
\hline $\begin{array}{l}\text { Modal verbs of inclination } \\
\text { (median, intention) }\end{array}$ & (倒) 想 (xiang wish) \\
\hline $\begin{array}{l}\text { Modal verbs of inclination } \\
\text { (low, willingness) }\end{array}$ & 愿意 (yuanyi will) 肯 (ken will) \\
\hline $\begin{array}{l}\text { Modal adverbs of inclination } \\
\text { (high) }\end{array}$ & $\begin{array}{l}\text { 一定 (yiding must) 偏 (pian must) } \\
\text { 非 (fei must) }\end{array}$ \\
\hline $\begin{array}{l}\text { Modal verbs of obligation } \\
\text { (high, compulsion) }\end{array}$ & $\begin{array}{l}\text { 要 (yao must) 必須 (bixu must) } \\
\text { 得 (dei must, the most colloquial form) }\end{array}$ \\
\hline $\begin{array}{l}\text { Modal verbs of obligation } \\
\text { (median, expectation) }\end{array}$ & $\begin{array}{l}\text { 应该 (yinggai } \text { should) 应当 (yingdang should) } \\
\text { 该 (gai should) }\end{array}$ \\
\hline $\begin{array}{l}\text { Modal verbs of obligation } \\
\text { (low, permission) }\end{array}$ & $\begin{array}{l}\text { 可以 (keyi may) 许 (xu allow) } \\
\text { 准 (zhun allow) } \\
\text { 得 (de) should—always used in its negative form- } \\
\text { “不得” ( bude) should not-to indicate prohibition }\end{array}$ \\
\hline
\end{tabular}


(Table 17 continued)

\begin{tabular}{|c|c|}
\hline $\begin{array}{l}\text { Type of modality } \\
\text { (Value) }\end{array}$ & $\begin{array}{l}\text { Positive shading modality } \\
\text { deontic, boulomaic systems foregrounded, generics, and verba sentiendi present }\end{array}$ \\
\hline Full verbs and nouns of obligation & $\begin{array}{l}\text { verbs such as 要求 (yaoqiu require) } \\
\text { 强迫 (qiang po compel) 让 (rang let) } \\
\text { 允许 (yunxu permit); } \\
\text { nouns such as 义务 (yiwu duty) } \\
\text { 责任 (zeren responsibility) } \\
\text { 许可 (xuke permission) } \\
\text { 只宜 (zhiyi can only be) } \\
\text { 做得到 (zuodedao can) } \\
\text { 尽 (jin can) }\end{array}$ \\
\hline $\begin{array}{l}\text { Boulomaic modality—-modal lexical verbs } \\
\text { indicating the wishes and desires of the } \\
\text { speaker }\end{array}$ & $\begin{array}{l}\text { (倒真)希望 (zhenxiwang) } \\
\text { (倒)情愿 (dao) (qingyuan) } \\
\text { 真盼望 (zhenpanwang) 巴望的事儿 (bawangdeshier) } \\
\text { 我的愿望 (wodeyuanwang) } \\
\text { (想)要(xiang (yao) }\end{array}$ \\
\hline
\end{tabular}

Table 18

Negative Shading Modality in Chinese System With Reference to Simpson's Point of View Model (1993)

\begin{tabular}{|c|c|}
\hline $\begin{array}{l}\text { Type of modality } \\
\text { (Value) }\end{array}$ & $\begin{array}{l}\text { Negative shading modality } \\
\text { (epistemic and perception systems foregrounded, supplemented with generalised } \\
\text { “words of estrangement”) }\end{array}$ \\
\hline $\begin{array}{l}\text { Modal verbs } \\
\text { (low) }\end{array}$ & $\begin{array}{l}\text { 可能 (keneng can) (也)会 (ye) (hui can) } \\
\text { 还可 (haike may) 还会 (haihui may) } \\
\text { 可要是 (keyaoshi might have) } \\
\text { 倒是 (daoshi will) }\end{array}$ \\
\hline $\begin{array}{l}\text { Modal verbs } \\
\text { (high) }\end{array}$ & $\begin{array}{l}\text { (总) (该) (gai should) } \\
\text { 该是 (gaishi may) }\end{array}$ \\
\hline $\begin{array}{l}\text { Modal adverbs } \\
\text { (high) }\end{array}$ & \begin{tabular}{|l} 
一定 (yiding must) 肯定 (kending must) \\
必定 (biding must) 准 (zhun must)
\end{tabular} \\
\hline $\begin{array}{l}\text { Modal adverbs } \\
\text { (median) }\end{array}$ & 大概 (dagai probably) 多半 (duoban probably) \\
\hline $\begin{array}{l}\text { Modal adverbs } \\
\text { (low) }\end{array}$ & $\begin{array}{l}\text { 也许 (yexu perhaps) 或许 ( huoxu perhaps) } \\
\text { 没准儿 (meizhuner maybe, perhaps) } \\
\text { 怕也未必 (payeweibi perhaps) } \\
\text { 说不定 (shuobuding maybe) }\end{array}$ \\
\hline $\begin{array}{l}\text { Full verbs of knowledge, prediction, and } \\
\text { evaluation }\end{array}$ & $\begin{array}{l}\text { 相信 (xiangxin believe) 估计 (guji estimate) 看 (kan think) 想 (xiang reckon) } \\
\text { 我摸不透 (womobutou I do not know) } \\
\text { 我弄不懂 (wonongbudong I do not know) } \\
\text { 我不知道 (wobuzhidao I do not know) } \\
\text { 真不知道 (zhenbuzhidao I do not know) } \\
\text { 我猜想 (wocaixiang I suppose) } \\
\text { 我看该是 (wokangaishi I suppose) } \\
\text { 我想是 (woxiangshi I suppose) } \\
\text { 我猜想一定是 (wocaixiangyidingshi I suppose) } \\
\text { 不明白 (bumingbai I wonder) } \\
\text { 我不晓得 (wobuxiaode I wonder) } \\
\text { 不知 (buzhi I wonder) }\end{array}$ \\
\hline
\end{tabular}




\section{Conclusions}

In this study, the author conducted comparative descriptions of aspects of the transitivity and modality systems of the Chinese language on the basis of the description of the English lexicogrammar against the background of a general systemic functional theory of language. The descriptions are grounded on selected examples of text instances drawn from two parallel corpora of 1,388 clause complexes compiled from four Chinese translations of a narrative of a novella in English. The contributions of the present study lie in the attempts to treat and describe translated texts as a phenomenon in its own right, and to develop delicate lexicogrammatical analyses of the source text and its corresponding target texts mostly at the ranks of clause and group as the "units of translation". The author found close resemblance between the two languages at the higher level of discourse semantics, but noticeable variations between them at the lower level of lexicogrammar. This is manifested particularly in the realization of the unique features of the transitivity system in Chinese with regard to: (1) aspect and phase; (2) coverbal phrase; (3) the dispositive " $b a$ " construction; (4) circumstance preceding process; and (5) serial verbal construction. As for modality of the interpersonal metafunction, attempts are made to compare the modulation and modalization systems between English and Chinese, and propose a set of modals categorized under the positive shading modality and the negative shading modality of Simpson's (1993) model for the investigation of narrative point of view in Chinese translated texts. The study supports that Chinese language displays specific linguistic features that should be explained and described in its own right within the system of the Chinese grammar. It also supports the applicability of systemic functional linguistics for the description of both English and Chinese languages even though modifications to the lexicogramatical features of the Chinese language would have to be made according to the purpose of study for the analysis of Chinese translated texts. With regard to research methodology, the accounts of the English and Chinese languages provided in this study are based primarily on descriptions of limited samples of text instances, which are qualitative in nature. Although the study also incorporates a quantitative profile to a limited degree such as by providing lists of ten more examples from the transitivity corpus (see the Appendix of this study) to contribute further textual instances for each category of the lexcicogrammar proposed to be adjusted for the Chinese transitivity system, still, a larger sample of descriptions can be drawn to test the validity of the Chinese transitivity system network. Therefore, future research could consider conducting a computer-assisted corpus study on the basis of the parallel corpus of the 1,277 clauses of the five process types compiled to investigate systematically the total number of instances that are accumulated in support of each of the five categories of the lexciogrammatical aspects of the transitivity system suggested to be adjusted according to the Chinese language for comparative translation description. Nevertheless, this empirical study demonstrates how translated texts are instantiation of the language system, and how the textual instances created from selected samples contribute further evidence to support the meaning potentials of both the English and the Chinese systems.

\section{References}

Beckett, S. (1950). Molloy. Lonbdon: Faber \& Faber.

Bronte, C. (1847). Jane Eyre. London: Penguin classics.

Caffarel, A., Martin, J. R., \& Matthiessen, C. M. I. M. (2004). Language typology: A functional perspective. Amsterdam: John Benjamins Publishing Company.

Chandler, R. (1940). Farewell, my lovely. London: Penguin Books Ltd.. 
Conrad, J. (1907). The secret agent. U.S.A.: Oxford World's Classics.

Flaubert, G. (1856). Madame Bovary. Oxford: Oxford University Press.

HAI, G. (Tans.). (1957). Lao Ren Yu Hai (The old man and the sea). Shanghai: Xin Wenyi.

Halliday, M. A. K. (1994). An introduction to functional grammar (2nd ed.). London, New York, Sydney, and Auckland: Arnold.

Halliday, M. A. K., \& Matthiessen, C. M. I. M. (1999). Construing experience through meaning: A language-based approach to cognition. London and New York: Cassell.

Halliday, M. A. K., \& McDonald, E. (2004). Metafunctional profile of the grammar of Chinese. In A. Caffarel, J. R. Martin, \& C. M. I. M. Matthiessen (Eds.), Language typology: A functional perspective (pp. 305-396). Amsterdam and Philadelphia: John Benjamins.

HAN, Y. (2005). Introduction to semantics and pragmatics (Distance learning course materials). Hong Kong: The Open University of Hong Kong.

Hemingway, E. (1928). "The Killers” in the complete short stories of Ernest Hemingway. New York: Scribner.

Hemingway, E. (1952). The old man and the sea. London: Arrow Books.

HUANG, G. W. (2006). Fanyi yanjiu de yuyanxue tansuo: Gushici Yingyiben de yuyanxue fenxi (Linguistic explorations in translation studies: Analyses of English translations of ancient Chinese poems and lyrics). Shanghai: Shanghai Waiyu Jiaoyu.

James, H. (1903). The ambassadors. U.S.A.: Oxford's World's Classics.

Kafka, F. (1925). The trial. London: Vintage Classics.

Li, E. S. H. (2003). A text-based study of the grammar of Chinese from a systemic functional approach (Unpublished Ph.D. dissertation, Macquarie University, Sydney).

Li, E. S. H. (2005). Voice in Chinese: A systemic functional perspective. Functions of Language, 12(2), 181-203.

Li, E. S. H. (2007). A systematic functional grammar of Chinese. London: Continuum.

LI, X. Y. (Trans.). (1987). Lao Ren Yu Hai (The old man and the sea). Sichuan:Sichuan Wenyi.

LI, Y. X. (2001). Yupian fanyi yinlun (An introduction to discourse and translation). Beijing: Zhongguo Duiwai Fanyi Chuban Gongsi.

LI, Y. X. (2002). “Zhuwei” gainian zai fanyi janjiuzhong de yingyong (The application of the concept of theme in translation research). Foreign Languages and Their Teaching, 7, 19-22.

Matthiessen, C. M. I. M. (2001). The environment of translation. In E. Steiner, \& C. Yallop (Eds.), Exploring translation and multilingual text production: Beyond content (pp. 41-124). New York: Mouton de Gruyter.

Munday, J. (2001). Introducing translation studies: Theories and applications. London and New York: Routledge.

Munday, J. (2002). Systems in translation: A systemic model for descriptive translation studies. In T. Hermans (Ed.), Crosscultural transgressions: Research models in translation studies II: Historical and ideological issues (pp. 76-92). Manchester: St Jerome.

Ng, E. Y. L. (2010). Translating style -Four Chinese translations of Hemingway's The Old Man and the Sea in modern China (1956-1987). Germany: Lambert Academic Publishing.

PENG, W. H. (1993). A thematic analysis of two Chinese essays. In Y. S. Chu (Ed.), Language, text, context (pp. 140-157). Beijing: Qinghua Daxue Chubanshe.

SHANG, Y. Y. (2003). A holistic theory of context and translation studies. Translation Quarterly, 28, 18-35.

Simpson, P. (1990). Modality in literary-critical discourse. In W. Nash (Ed.), The writing scholar studies in academic discourse (Vol. 3, pp.63-94). London et al.: Sage Publications.

Simpson, P. (1993). Language, ideology and point of view. London and New York: Routledge.

WU, L. (Trans.). (1987). Chun Chao/Lao Ren Yu Hai (Torrents of spring/the old man and the sea). Shanghai: Shanghai Yiwen.

XIU, L. M. (2001). Xin Yixue Lungao (Discussion on new translation studies). Beijing: Zhongguo Duiwai Fanyi Chuban Gongsi.

Yip, P. C., \& Rimmington, D. (1997). Chinese: An essential grammar. London and New York: Routledge.

ZHANG, M. F. (2005). Fanyi yanjiu de gongneng tujing (Functional approaches to translation studies). Shanghai: Shanghai Waiyu Jiaoyu.

ZHAO, S. W. (Trans.). (1987). Lao Ren Yu Hai (The old man and the sea). Lijiang: Lijiang Chubanshe.

ZHU, Y. (1996). Modality and modulation in Chinese. In M. Berry, C. Butler, R. Fawcett, \& G. HUANG (Eds.), Meaning and form: Systematic functional interpretations (pp. 183-209). Norwood, New Jersey: Ablex Publishing Corporation. 


\section{Appendix: Selected Examples From the Transitivity Corpus of \\ Hemingway's The Old Man and the Sea Compiled by Ng (2010)}

1. Examples of aspect and phase in Chinese

(1) Verbal (Perfective ) Aspect

(a) 他抓紧了背在脊梁上的钓丝 (HAI ,7)

(b) 他攥住了勒在背脊上的钓索 (WU, 7)

(c) 伸出手放到海水里去洗, 在水里浸了一分多钟的工夫 (HAI, 10)

(d) 在海水里洗手, 把手在水里浸了一分多钟 (WU, 10)

(e) 右手伸进海水里泡了一兩分钟 (LI, 10)

(f) 把右手伸進海里去洗, 泡了一分多钟 (ZHAO, 10)

（g）老人这时用他的左手和肩膀拽住了它 (WU, 14)

(h) 老人这时用他的左手和肩膀拽住了它 (WU, 19)

(i) 他放下了桅杆站起来 (HAI, 34)

（j）他又拿了一整条鱼肉嚼起来 (ZHAO, 40)

(2) Verbal (Imperfective) Aspect

(a) 忍受著袭来的痛楚感 (WU, 41)

(b) 好歹忍受焦疼痛。(LI, 41)

(c) 难受了便忍着。(ZHAO, 41)

（d）他小心翼翼地拿着钓丝，不让它经过新给钓丝勒过的任何一条痕迹上。(HAI, 43)

（e）他小心地攥着钓索，使它不致嵌进新勒破的任何一道伤痕 (ZHAO, 43)

(f) 他忍住一切的疼痛，抖擞抖擞当年的威风，把剩下的力气统统拼出来,用来对付鱼在死亡以前的挣扎。 (HAI, 48)

（g）他忍住各种疼痛，鼓起仅存的力量和早已衰减的少年意气，用作孤注押在垂死的大鱼身上。(ZHAO, 48)

(h) 用一个套索拴焦它的尾巴 (HAI, 89)

(i) 用一根套索拴住它的尾巴 (HAI, 89)

(j) 用一个绳套套住尾巴 (HAI, 89)

(3) Clausal (Perfective) Aspect

(a) 这是他从木船板上抬起头来，不再贴在那片被他脸规压烂的鱼肉上了。(WU, 83)

(b) 他深信鱼再转两个圈儿他就可以乘机会把与叉攘在它身上了。(HAI, 85)

(c) 他敢肯定 : 再有两圈, 就用得者钢叉了。(LI, 85)

（d）它不会攒到很深的水里, 死在我无法把它拖上来的地方了。(HAI, 96)

(e) 後艄绕在他脚下的一根钓丝绷紧了。(LI, 101)

(f) 船後梢那根钓绳本来有一圈被他踩着的, 这时候在他脚下变紧了。(ZHAO, 101)

(g) 到最後, 左手也抓住钓绳了, (ZHAO, 172)

(h) 顿时老人使出全身气力，把对方的手压得低下、低下，终于碰到桌面了。(LI, 183)

(i) 但他找不到假饵，而沙丁鱼又都烂掉了。(LI, 198)

（j）但他找不著勺儿钩, 他那些沙丁鱼都坏了。(ZHAO, 198)

2. Phase System in Chinese

(1) Completive Phase-Directional (realized by a post-verb)

（a）他鼓起全身的气力，用他染了血的手把一杆锋利无比的鱼叉扎了进去。(HAI, 201) 
(b) 他使出全身的力气, 用糊着鲜血的雙手，把一支好鱼叉向它扎去。(WU, 201)

(c) 他用两只血糊糊的手来扎, 使出全身力气将一把好铁叉往里杵进去。(ZHAO, 201)

（d）他向它扎去的时候并没有抱着什么希望，(HAI, 202)

(e) 老人趁它的鼻子伸出水面挨上那条鱼的時候，对准它扁平的脑袋正中扎去。(WU, 204)

(f) 于是又朝同一个部位打去, (HAI, 209)

（g）所以他在船经过的时候用鱼叉钩上一块黄黄的马尾藻，(HAI, 217)

(h) 老汉从钩上卸下死鱼 (ZHAO, 216)

(i) 把两盘钓丝卷儿连接起来。(HAI, 219)

(j) 把它砍断，把余下的两盘绳子连上。(ZHAO, 219)

(2) Completive Phase-Resultative (realized by a post-verb)

(a) 就把它剖开来。(WU, 237)

(b) 撕开一看 (ZHAO, 237)

(c) 他知道, 如果他不能使出一定的劲儿叫鱼游得慢一些, 鱼就會把钓丝统统拖去, 把它扯断的。(HAI, 242)

(d) 老头儿用拇指和食指把它們的头掐掉，(HAI, 254)

(e) 他把鱼叉准备好 , (HAI, 244)

(f) 往日也曾提到过两条那么大的 , 不过不是他一个人捉到的。(HAI, 250)

（g）老汉伸出拇指和食指掐掉虾头便吃, (ZHAO, 254)

(h) 赶快把她宰完拉倒。(HAI, 258)

(i) 他洗了左手, 在裤腿上擦乾。(LI, 305)

（j）他把布袋垫好，(LI, 341)

3. Coverbal Phrases

(a) 然後拿大腿抵住了右手，把全身的重量压在船头的木板上。(WU, 337)

(b) 接著,当他把全身重量压到船头木板上的时候，便用大腿顶住右手。(ZHAO, 337)

(c) 把左手啪地紧按在大腿上 (WU, 344)

(d) 不让它滑到掌心或勒着手指。(LI, 382)

(e) 把全身的重量放在右手上, (WU, 441)

(f) 把整个身体都压到右手上 (LI, 441)

（g）他的左手仍旧在抽筋，他慢慢地在张开它。(HAI, 468)

(h) 現在回到船梢去处理那条鲯鳅吧。(WU, 507)

(i) 打船边向外面小便。(HAI, 559)

(j) 向舷外撒一泡尿, (LI, 559)

4. The Dispositive $b a$ Construction

（a）整整一天一夜，他們把手拐儿搁在桌面一道粉笔线上，胳膊朝上伸直,两只手紧握着。(WU, 562)

（b）他两用粉笔在桌上面画两道线，各人把胳膊肘放到线上，伸出前臂，紧握两手，相持了一天一夜。(LI, 562)

(c) 在海水里洗手, 把手在水里浸了一分多钟, (WU, 565)

(d) 伸出一只手去把那只水瓶拿过来。(HAI, 627)

(e) 把身子安靠在船头的边缘已被磨圆的木板上, (WU, 642)

（f）他又把麻袋围在肩膀上 , (HAI, 646)

（g）他把麻袋在肩头围好，(WU, 646) 
（h）他把肩上的布袋披好，(LI, 646)

(i) 把身子仰到後面去撑往压在他脊梁上的拉力。(HAI, 654)

(j) 把对抗鱼的拉力的任务越来越让小船本身来承担了。(WU, 674)

5. Circumstance Before Processes

(a) 别处海滩上也有其他一些船只驶出海去。(HAI, 1231)

(b) 其他那些海滩上也有其他船只在出海, (WU, 1231)

(c) 头上有高高的积云, 还有很多的卷云, 所以老头儿知道还要刮一整夜的小风。(HAI, 1249)

（d）老头儿看见别的船只低低地伏在水面上，船头都对着海岸，在海流中散开，向著海岸驶去。(HAI, 756)

(e) 老头儿看见一条飞鱼从水里跃出，从水面上拼命地飞过去。(HAI, 757)

(f) 老人看见飞鱼从水里跃出，在海面上拼命地掠去。(WU, 757)

(g) 看到在黄昏中走上海滩来的第一头狮子，接著别的狮子也出现了。(HAI, 762)

(h) 看见第一头狮子在傍晚时分来到海滩上, 接著其他狮子也来了 (WU, 762)

(i) 他第一次看见它是在它跃出水面的当儿，在最後一线阳光中确实像金子一般，在空中弯起身子，疯狂地扑打着。 (WU, 770)

(j) 感觉到从他曳在肩头的钓丝上透过来的那条大鱼的重量，那根钓丝朝著大鱼所选择的方向缓缓地移动了开去。 (HAI, 820)

6. Serial Verbal Constructions
(a) 我要把两个桨放在船梢交叉着绑在一起 (HAI, 169)
(b) 他使出了浑身的气力, 逼著黑人的手往下落, 落, 一直落到把那只手靠在桌面上。(HAI, 183)
(c) 他把舵柄夹在胳肢窝里, 用脚踩住帆脚绳, 把刀子绑在桨把上了。(HAI, 262)
(d) 他又试了一下, 等他把鱼拉得转过来时, 他感到自己要垮了。(WU, 316)
(e) 然後他把手张开, 再轻轻捏住了桨, 让双手松弛下來。(WU, 417)
(f) 但是当他拉到快要折断的地步时, 他就拉住了不动, 然後把身子往後仰着去抵挡钧丝的张力。(HAI, 448)
(g) 但是拉到快崩断的当儿, 他就握稳了钓索, 身子朝後倒, 来抵消钓索上的那股拉力。(WU, 448)
（h）他趾下，用挽钩拨出後艄的金枪鱼，好不容易避开盘着的繩子，把鱼儿拖到面前。(LI, 454)
(i) 回到船艄以後, 他掉转身子, 让左手接过他脊背上那根钓绳的坠力, (ZHAO, 540)
（j）但是当他拉到快要折断的地步时，他就拉住了不动，然後把身子往後仰著去抵当钓丝的张力。(HAI, 644) 